\title{
Tectonothermal evolution in the core of an arcuate fold and thrust belt: the south-eastern sector of the Cantabrian Zone (Variscan belt, north-western Spain)
}

\author{
María Luz Valín, Susana García-López, Covadonga Brime, Fernando Bastida, and Jesús Aller \\ Departamento de Geología, Universidad de Oviedo, 33005 Oviedo, Spain \\ Correspondence to: Fernando Bastida (bastida@geol.uniovi.es)
}

Received: 16 March 2016 - Published in Solid Earth Discuss.: 4 April 2016

Revised: 10 June 2016 - Accepted: 17 June 2016 - Published: 11 July 2016

\begin{abstract}
The tectonothermal evolution of an area located in the core of the Ibero-Armorican Arc (Variscan belt) has been determined by using the conodont colour alteration index (CAI), Kübler index of illite (KI), the Árkai index of chlorite (AI) and the analysis of clay minerals and rock cleavage. The area is part of the Cantabrian Zone (CZ), which represents the foreland fold and thrust belt of the orogen. It has been thrust by several large units of the $\mathrm{CZ}$, what resulted in the generation of a large number of synorogenic Carboniferous sediments. CAI, KI and AI values show an irregular distribution of metamorphic grade, independent of stratigraphic position. Two tectonothermal events have been distinguished in the area. The first one, poorly defined, is mainly located in the northern part. It gave rise to very-low-grade metamorphism in some areas and it was associated with a deformation event that resulted in the emplacement of the last large thrust unit and development of upright folds and associated cleavage $\left(S_{1}\right)$. The second tectonothermal event gave rise to lowgrade metamorphism and cleavage $\left(S_{2}\right)$ crosscutting earlier upright folds in the central, western and southern parts of the study area. The event continued with the intrusion of small igneous rock bodies, which gave rise to contact metamorphism and hydrothermal alteration. This event was linked to an extensional episode due to a gravitational instability at the end of the Variscan deformation. This tectonothermal evolution occurred during the Gzhelian-Sakmarian. Subsequently, several hydrothermal episodes took place and local crenulation cleavage developed during the Alpine deformation.
\end{abstract}

\section{Introduction}

The Variscan belt defines an arc in the north-western Iberian Peninsula (Ibero-Armorican Arc) whose core is formed by the Cantabrian Zone (CZ), which represents the foreland fold and thrust belt of the orogen (Fig. 1). This zone consists of Palaeozoic rocks in which two tectonostratigraphic units have been distinguished (Julivert, 1978; Marcos and Pulgar, 1982), whose limit is approximately located by the Devonian-Carboniferous boundary. The pre-orogenic unit is formed of Cambrian to Devonian rocks consisting of alternating carbonate and siliciclastic formations; they form a wedge that thins towards the foreland. The synorogenic unit is formed by several clastic units, also thinning towards the foreland, which filled foredeep basins generated in the front of the main thrust units of the CZ. In this zone, the Variscan deformation occurred during the upper Carboniferous and gave rise to thin-skinned tectonics, with several large thrust units and associated folds (Fig. 1); the units were emplaced in a sequence towards the foreland. The deformation occurred under shallow crustal conditions, so that diagenetic conditions are dominant in the zone and absence of cleavage in the rocks is also dominant. Nevertheless, there are several areas of the $\mathrm{CZ}$ where cleavage and very-low- or low-grade metamorphism are present. One of these areas is the south-eastern sector of the CZ. It is a foreland basin that occupies the core of the Ibero-Armorican Arc and has undergone a complex history of sedimentation, deformation, metamorphism and, to a lesser extent, magmatism.

The present study aims to present a model of tectonothermal evolution for the core of the Ibero-Armorican Arc based on conodont colour alteration index (CAI), the Kübler index 


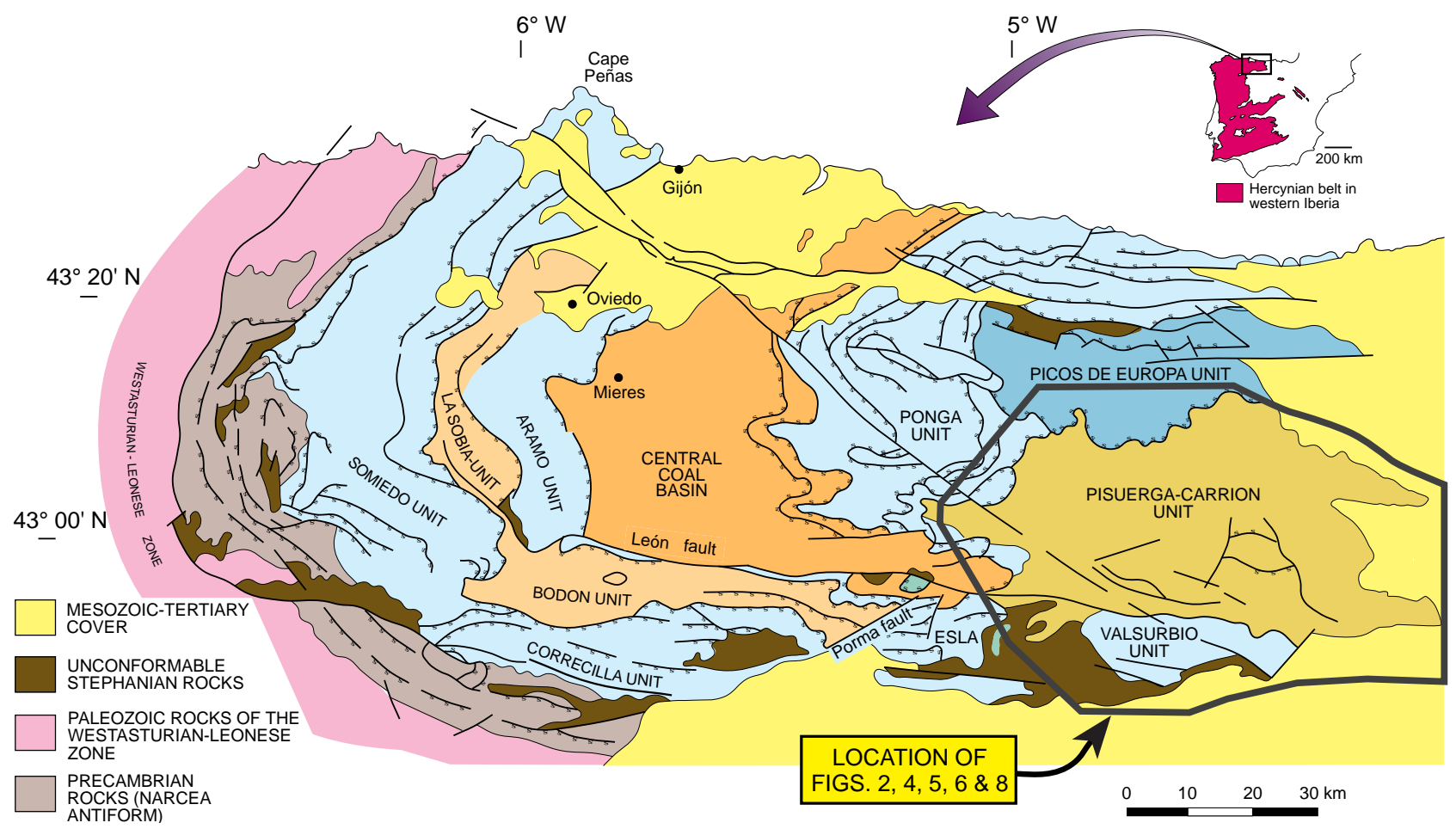

Figure 1. Generalized geological map of the Cantabrian Zone (after Julivert 1971) showing major thrust units and the location of the study area.

(KI) of illite, the Árkai index (AI) of chlorite (Chl), the analysis of clay minerals and the rock cleavage development.

\section{Geological setting}

The south-eastern sector of the $\mathrm{CZ}$ is made up of two units: the Pisuerga-Carrión unit (PCU) and the Valsurbio unit (VU) (Fig. 1). As a consequence of its location in the core of the Ibero-Armorican Arc, the PCU has been thrust over successively by the VU, the Central Coal Basin, the Ponga unit and the Picos de Europa unit (Fig. 1). Thus, the PCU operated as a foreland basin during a great part of the history of the Variscan deformation. This history involved the accumulation of a great thickness of synorogenic Carboniferous sediments, corresponding to clastic wedges associated with the exhumation of the thrust units.

The VU is located to the south of the PCU. Marine facies occur in both units, but from the Emsian the sediments in the latter unit were deposited in deeper waters than those in the former unit. The VU represents an extension of the southern part of the CZ, and the Devonian succession of both is comparable (Koopmans, 1962). The units within the PCU containing Silurian-Devonian rocks have been interpreted as transported from internal areas of the orogenic belt, specifically from the south-eastern extension of the West Asturian-Leonese Zone, currently hidden under the Mesozoic-Cenozoic cover of the Douro basin and located to the south of the VU (Frankenfeld, 1983; Marquínez and Marcos, 1984; Rodríguez Fernández and Heredia, 1987; Rodríguez Fernández, 1994). These units were named "Palentine nappes" by Rodríguez Fernández and Heredia (1987). The PCU and the VU are separated by the León fault (also called "Ruesga fault" in the study area) (Fig. 2) that crosses most of the $\mathrm{CZ}$ and whose meaning is controversial (Alonso et al., 2009 and references therein).

The oldest sediments of the study area are Silurian (Wenlock-Pridoli) sandstones and lutites. The Devonian rocks consist of an alternation of carbonate and siliciclastic formations with the facies differences cited above. Mississippian rocks are mainly limestones in the lower part, especially in the VU; upwards a mostly turbiditic sequences appears with common olistoliths in the northern sector and some carbonate levels. The Pennsylvanian succession is dominantly siliciclastic, with a thickness of several thousand metres and synorogenic character. In relation to this synorogenic sedimentation, several syntectonic unconformities have been described, among which the Curavacas unconformity (early Moscovian) can be highlighted by its structural significance (Van Veen, 1965; Lobato, 1977; Alonso and Rodríguez Fernández, 1983; Martín-Merino et al., 2014).

The first deformation events were pre-Curavacas (prior to or earliest Moscovian) and involved the emplacement of the Palentine nappes and the VU. Two generations of thrusts and associated folds occurred during this episode (Rodríguez 


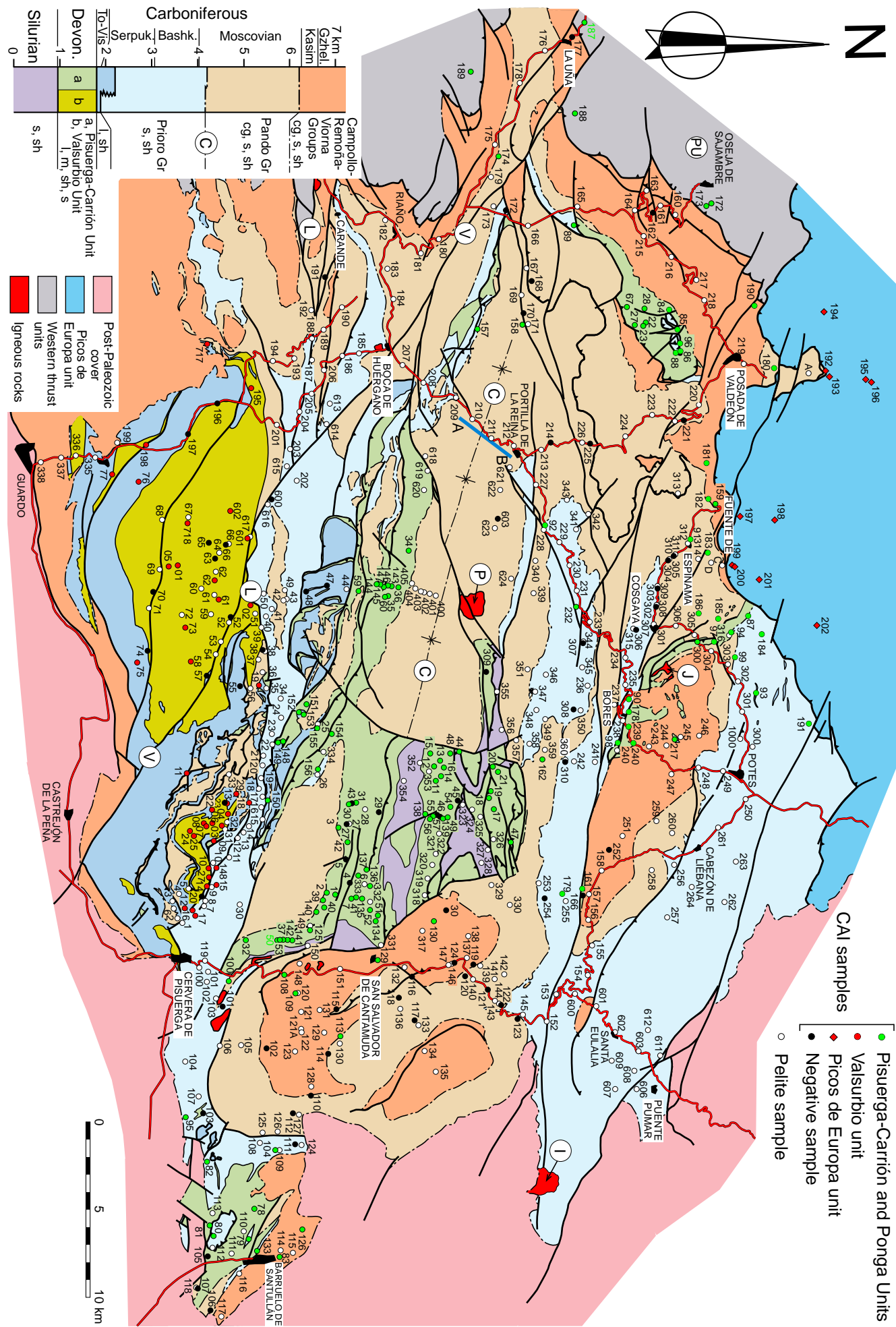

Figure 2. Geological map of the south-eastern part of the Cantabrian Zone showing sampled localities (composed from Lobato, 1977; Colmenero et al., 1982; Ambrose et al., 1984; Julivert and Navarro, 1984; Martínez García et al., 1984; Lobato et al., 1985; Heredia et al, 1986, 1991, 1997; Rodríguez Fernández, 1994; Rodríguez Fernández et al., 1994). Devonian and Silurian rocks of the PCU form the Palentine nappes; cg - conglomerate; 1 - limestone; $\mathrm{m}$ - marl; s - sandstone; sh - shale. C - Curavacas-Lechada syncline; I - Pico Iján granodiorite; J. Pico Jano granodiorite; L - León fault; P - Peña Prieta granodiorite; PU - Ponga unit; V - Ventaniella fault. Picos de Europa conodont samples after Bastida et al. (2004); Valsurbio conodont samples after García-López et al. (2013). A-B indicates the location of cross section in Fig. 11. 
Fernández, 1994), which translated sequences northwards. Further, some back thrusts and normal faults occurred.

The post-Curavacas deformation events involved the development of several generations of thrusts and high-angle reverse faults, folds, cleavages and normal faults. Some thrusts have a trend approximately parallel to the basal thrust of the Ponga unit and are probably related to the emplacement of this thrust unit (Rodríguez Fernández and Heredia, 1987), which occurred during the late Moscovian. In the same episode that involved the emplacement of the Picos de Europa thrust unit during the Kasimovian-Gzhelian (Merino-Tomé et al. 2009), N-S shortening occurred in the study area, involving the development of thrusts, high-angle reverse faults and the reactivation of older faults with a movement dominantly southward (Maas, 1974). In addition, upright folds with E-W axial trace developed; among them, the Curavacas-Lechada syncline is remarkable for its notable dimensions (Savage, 1967; Lobato, 1977; Rodríguez Fernández, 1994).

Several cleavages have been recognised in the study area. Among them, a gently dipping cleavage crosscutting folds is the most relevant and has been described by various authors (Van Veen, 1965; Savage, 1967; Lobato, 1977; Van der Pluijm et al., 1986; Rodríguez Fernández, 1994; Marín, 1997; García-López et al., 2007; and reference therein).

A subsequent $\mathrm{N}-\mathrm{S}$ shortening episode occurred during the Alpine deformation. It involved tightening of folds, local development of crenulation cleavage and reactivation of some faults. It is responsible for the dome geometry of the VU (Marín et al., 1995; Marín, 1997). Another post-Variscan structure of the study area is the Ventaniella fault, which traverses the whole $\mathrm{CZ}$ in a NW-SE direction. It is essentially a dextral, strike-slip fault with a net slip of 4-5 km (Julivert et al., 1971) whose activity began in the Permian and continues to the present (López-Fernández et al., 2004).

Outcrops of intrusive igneous rocks are common in the PCU, and their knowledge is important to understand the tectonothermal evolution of this unit. Among these rocks, three granodioritic stocks (Pico Iján, Peña Prieta and Pico Jano; Fig. 2) and many small outcrops can be distinguished. The latter are mainly concentrated in the southern half of the unit.

The stocks of Pico Iján, Peña Prieta and Pico Jano dominantly have granodioritic composition and their intrusion was favoured by the existence of faults (Suárez and García, 1974; Corretgé and Suárez, 1990), having developed a notable aureole of contact metamorphism in the case of the Peña Prieta stock. The porphyroblasts in this aureole are post-tectonic relative to the gently dipping cleavage (Gallastegui et al., 1990; Rodríguez Fernández, 1994). The U/Pb age of the Peña Prieta granitoid is Cisuralian (292+3/-2 Ma after ValverdeVaquero et al., 1999), and the Pico Iján granitoid is nonconformably covered by Lower Triassic rocks. The large number of small outcrops of igneous rocks that exist in the southern half of the unit are concentrated in two areas (one in the eastern part and another in the western part) joined by a band whose outcrops of igneous rocks have been related to the León fault (Corretgé et al., 1987; Suárez and Corretgé, 1987; Corretgé and Suárez, 1990). All these southern outcrops have been, in general, related to fractures and appear as small stocks, probably apophyses of bigger bodies in depth, and as sills or dikes. Their composition is varied and ranges from granodioritic to gabbroic. In some cases, they developed ore bodies close to their contacts (Martín-Izard et al., 1986).

Earlier metamorphic studies in the CZ using CAI and/or KI methods have shown the existence of areas with verylow- or low-grade metamorphism in the PCU and the VU (Raven and van der Pluijm, 1986; Keller and Krumm, 1993; Marín et al., 1996; Marín, 1997; Köberle et al., 1998; GarcíaLópez et al., 1999, 2007, 2013; Bastida et al., 2002; Clauer and Weh, 2014, and references therein). Similar results have been obtained for the southern part of the study area using coal rank and vitrinite reflectance (Colmenero and Prado, 1993; Llorens et al., 2006; Colmenero et al., 2008; Clauer and Weh, 2014). This metamorphism has been described as associated with a late-orogenic extensional event and with the corresponding cleavage (García-López et al., 1999, 2007, 2013; Bastida et al., 2002). Analysis of ore deposits and of the tectonothermal evolution in the neighbouring unit of the Picos de Europa has defined a subsequent hydrothermal episode during the Permian (Gómez-Fernández et al., 1993, 2000; Bastida et al., 2004). Brime and Valín (2006) have suggested a hydrothermal origin for mineral associations with chloritoid (Cld) and pyrophyllite (Prl) found in samples of pelitic rocks collected in the study area. $\mathrm{K}-\mathrm{Ar}$ dating of illite in samples collected in the southern part of the study area identified four thermal episodes (Clauer and Weh, 2014), namely at (1) $293 \pm 3 \mathrm{Ma}$ (Cisuralian), (2) $268 \pm 6 \mathrm{Ma}$ (Guadalupian), (3) $243 \pm 5 \mathrm{Ma}$ (middle Triassic) and (4) $175 \pm 6 \mathrm{Ma}$ (early-middle Jurassic). Low-temperature thermochronology studies by Fillon et al. (2016) in three samples of Westphalian sandstones collected in the northern and central parts of the PCU, provided cooling ages below $180^{\circ} \mathrm{C}$ by 37-39 Ma. They inferred Cenozoic erosion of a rock thickness between 6.4 and $8 \mathrm{~km}$ (assuming a steady-state geothermal gradient of $25^{\circ} \mathrm{C} \mathrm{km}^{-1}$ ).

\section{Methods}

\subsection{X-ray diffraction (XRD)}

A total of 297 mudrocks from various localities (Fig. 2) were studied by XRD analysis in order to determine their phyllosilicate mineralogy, KI of illites and AI of chlorites. Preparation of samples and methods for XRD analysis follow the methods described in Brime et al. (2003)

Reaction progress in illitic minerals (sensu Środoń, 1984) has been widely used to assess the evolution of pelitic litholo- 
gies during diagenesis and low-grade metamorphism. Prograde changes can be identified by use of the KI technique (illite "crystallinity"; see Guggenheim et al,. 2002) involving quantification of the width of the $10 \AA$ peak of illite. This is an indirect measure of lattice reorganisation and thickening of illite crystals (Kisch, 1983; Merriman and Peacor, 1999) with increasing grade. The KI is expressed in $\Delta^{\circ} 2 \theta$ to minimise variations caused by differences in recording conditions. For this study the KI was measured using a laboratory procedure similar to that outlined by the IGCP 294 working group (Kisch, 1991). The numerical KI value decreases with improving "crystallinity" and is expressed as small changes in the Bragg angle $\Delta^{\circ} 2 \theta$, using $\mathrm{Cu} \mathrm{K} \alpha$ radiation.

The transient zone between diagenesis and metamorphism (the anchizone of Kübler, 1967) is defined by KI values between $0.42^{\circ}$ and $0.25 \Delta^{\circ} 2 \theta$ respectively (Kisch, 1991). The values obtained in our laboratory were correlated with the Kübler scale using a calibration curve based on data obtained from polished slate standards kindly provided by $\mathrm{H}$. Kisch. The diagenetic zone has been subdivided in shallow $\left(\mathrm{KI}>1 \Delta^{\circ} 2 \theta\right)$ and deep $\left(1.0^{\circ}>\mathrm{KI}>0.42 \Delta^{\circ} 2 \theta\right)$, using the terms proposed by the IUGS Subcommission on the Systematics of Metamorphic rocks (Árkai et al., 2007). Following Merriman and Peacor (1999) we have divided the anchizone into low $\left(0.42<\mathrm{KI}<0.30 \Delta^{\circ} 2 \theta\right)$ and high $(0.30<\mathrm{KI}<0.25$ $\Delta^{\circ} 2 \theta$ ).

Crystallinity index standards (CISs; Warr and Rice, 1994) have also been used to compare the results thus obtained with other published results using that scale. KI values obtained in this work could be converted to the CIS scale by using the calibration reaction:

$\mathrm{KI}_{\mathrm{CIS}}=1.505 \mathrm{KI}_{\text {this work }}-0.046\left(R^{2}=0.996\right)$.

For the problems involved in the use of the CIS scale to assess metamorphic grade, see Brime (1999) and Kisch et al. (2005).

The KI method does not allow temperature constraints to be placed on the upper and lower boundaries of the anchizone and it is more likely to be a measure of reaction progress than of the thermodynamic equilibrium achieved (Essene and Peacor, 1995). However, this method, in combination with others such as fluid inclusions or reflectance of carbonaceous material, indicates that the transition diagenesis-anchizone could be correlated with a temperature of $230 \pm 10^{\circ} \mathrm{C}$, whereas the limit anchizone-epizone would be at $300 \pm 10^{\circ} \mathrm{C}$ (Müllis, 1979; Frey et al., 1980; Frey, 1987; Von Gosen et al., 1991; Müllis et al., 1995, 2002; Merriman and Frey, 1999; Ferreiro Mählmann et al., 2002).

The presence of illite/smectite (I/S) and paragonite $(\mathrm{Pg})$ and paragonite/muscovite $(\mathrm{Pg} / \mathrm{Ms})$ hampers determination of KI of many samples. However, pro-grade changes can also be identified by use of the AI technique (of chlorite "crystallinity"; see Guggenheim et al., 2002) involving quantification of the width of the $14 \AA$ or $7 \AA$ peaks of chlorite (Árkai, 1991; Meunier, 2005). The AI was determined in the 002 peak using the same instrumental conditions as those for KI measurements. The anchizone limits have been established using samples free of I/S and $\mathrm{Pg}-\mathrm{Pg} / \mathrm{Ms}$ in which the KI measured in the air-dried samples has been calibrated with Kisch standards. The AI was measured in the same samples and the regression line obtained allowed the delimitation of the upper and lower anchizone limits using chlorite for AI values of 0.234 and $0.135 \Delta^{\circ} 2 \theta$ respectively. It should be noted that AI values are smaller than the corresponding $\mathrm{KI}$ and the method is therefore slightly less sensitive than KI method.

\subsection{Conodont colour alteration index}

Colour changes in conodont elements are related to the progressive and irreversible alteration of the amounts of organic matter within their apatite composition. The CAI method is based on analysis of the colour changes that the conodonts undergo in response of the organic matter to a temperature increase with time. These changes permit construction of a scale of CAI values with eight units that allows the use of the conodonts as maximum palaeothermometers for a temperature interval of between 50 and $600^{\circ} \mathrm{C}$ (Epstein et al., 1977; Rejebian et al., 1987). It is used mainly in carbonate rocks. Besides colour changes, apatite textural alteration also takes place and can provide complementary information about the thermal conditions. In the present paper the terminology of Rejebian et al. (1987) and García-López et al. (1997, 2006) is used for the textural description of conodonts. In agreement with Rejebian et al. (1987), well-preserved conodonts and high CAI values with a wide dispersion are indicative of contact metamorphism. Furthermore, coarse recrystallisation and corrosion are related to hydrothermal processes.

Samples were collected from the Pisuerga-Carrión and Valsurbio units. CAI values are based on $5 \mathrm{~kg}$ samples of limestone that were treated with $6 \%$ acetic acid solution. Unfortunately, recovery of conodonts from Carboniferous rocks was hindered in some areas by their dominantly siliciclastic character. Sampling was complemented with specimens from collections housed at the University of Oviedo (Spain) and those of the National Museum of Natural History at Leiden (Netherlands) and Institut und Museum für Geologie und Paläontologie in Göttingen (Germany) (Fig. 2); 213 positive samples, corresponding to an age interval from the Pridoli to Gzhelian, were analysed for CAI determination (Supplement 1 in the supplementary material).

The methodology involved in CAI determination can be found in García-López et al. (1997) and Bastida et al. (1999). Several CAI values were obtained from most samples and the mean of CAI values has been determined for each of them in order to tentatively contour CAI values. Samples with a range higher than 1.5 have not been used to obtain mean CAI values and temperatures. The interpretation of the results is mainly based on the analysis of the CAI isograds and their relationship to the stratigraphic contacts and the main structures of the study area. 


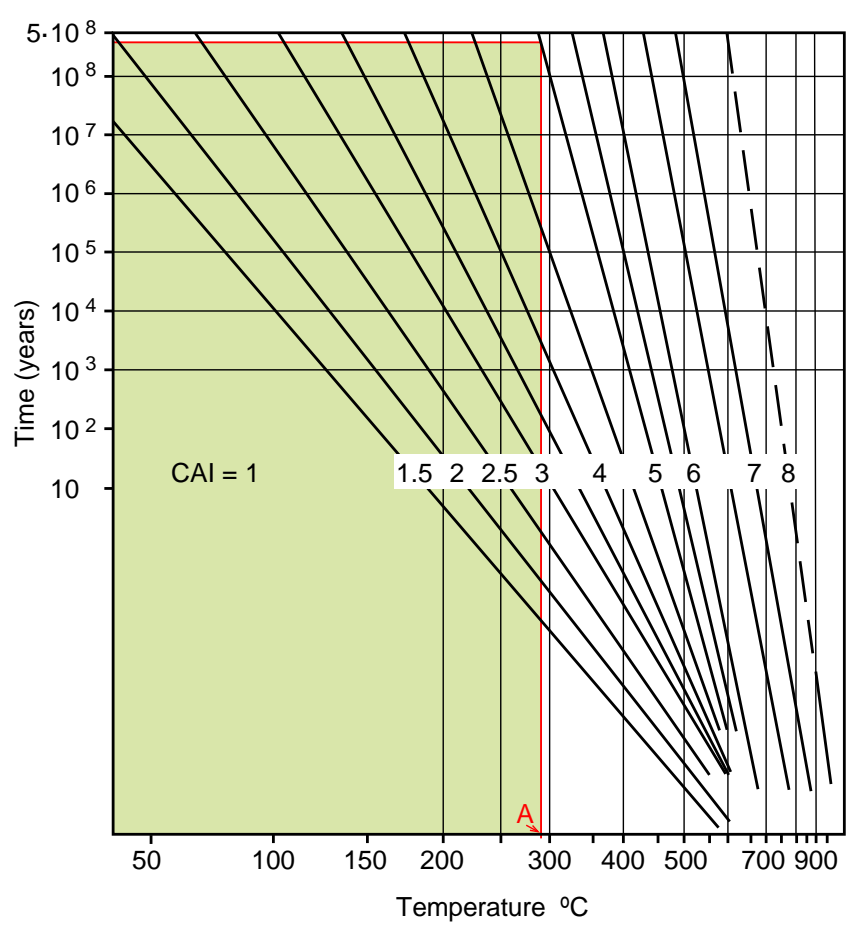

Figure 3. Arrhenius plot to determine palaeotemperature from CAI values (on the lines) and heating time (from Rejebian et al., 1987). Point A indicates the minimum temperature necessary to obtain a $\mathrm{CAI}=5$ for a rock with an age of $400 \mathrm{Ma}$. The green area shows the temperatures and heating times unable to produce $\mathrm{CAI} \geq 5$ in this rock.

For the metamorphic zonation from CAI data, we use the terminology described by García-López et al. (2001) that involves a division in diacaizone $(\mathrm{CAI}<4)$, ancaizone $(4 \leq \mathrm{CAI} \leq 5.5)$ and epicaizone $(\mathrm{CAI}>5.5)$.

Temperature ranges of the CAI values were obtained from the Arrhenius plot presented by Epstein et al. (1977) and Rejebian et al. (1987). The maximum possible heating time is the age of the rock. Nevertheless, it is possible to place greater limits on this maximum time (García-López et al., 2013). According to the Arrhenius plot a minimum temperature is required to obtain a specific CAI value. For example, in a rock with an age of $400 \mathrm{Ma}$ (Devonian), development of $\mathrm{CAI}=5$ requires at least $290^{\circ} \mathrm{C}$ (point A in Fig. 3). Then, it can be assumed that a temperature $<290^{\circ} \mathrm{C}$ does not contribute to the generation of a $\mathrm{CAI}=5$. Hence, to produce a given CAI, the maximum time of heating begins when the rock reaches the minimum temperature necessary to produce that CAI, and it ends when the rock cools down and the temperature becomes lower than this minimum value. Although the heating time can be slightly different depending on the geological location of the samples, we consider that the main heating time corresponds to a late-Variscan period that began at the boundary Kasimovian-Gzhelian and ended at the beginning of the Triassic (heating time of about $50 \mathrm{Ma}$ ); this agrees with the age of the metamorphism analysed below and the igneous rocks. The hydrothermal post-Variscan episodes described by Clauer and Weh (2014) probably involved lower temperatures than those reached in the late-Variscan event, in which magmatism and cleavage development are more intense. It must be taken into account that, in rocks undergoing more than one heating period, the period to be considered for the development of the CAI is the one which generated higher temperatures. In any case, due to the geometry of the CAI curves in the Arrhenius plot, for heating intervals such as those involved in the present case, an error of a few Ma in the maximum time of heating has little influence on the results. According to Patrick et al. (1985) and Rejebian et al. (1987), the minimum time of heating assumed here is $1 \mathrm{Ma}$.

\subsection{Cleavage}

Development of cleavage requires mineralogical and microstructural changes due to ductile deformation, involving mechanisms, such as pressure solution, that require a minimum temperature of about $200^{\circ} \mathrm{C}$ for cleavage development in pelitic rocks and $175^{\circ} \mathrm{C}$ in limestones (Groshong et al. 1984). Thus widespread presence of cleavage occurs below a certain crustal level (minimum overburden of 5-7 km; Engelder and Marshak, 1985). Furthermore, the relations between folds and cleavages and the overprinting relations between cleavages play an important role in defining deformation events (Passchier and Trouw, 2005). In addition, cleavage is also a key structure to establish chronological relations between metamorphic crystallisation and deformation.

In the context of the study area, we refer to a tectonothermal event as a deformational event with cleavage development and associated metamorphic conditions, and we use the term thermal event for metamorphic conditions without cleavage development.

\section{Results and interpretation}

In order to facilitate description, the samples have been mainly grouped in the following areas, namely Liébana, Valdeón, Yuso-Carrión, Pisuerga, Riaño-Cervera and Valsurbio (Fig. 4) (cf. Martín-Merino et al., 2014).

\subsection{Clay minerals}

\subsubsection{Clay mineral assemblages}

Mineralogical analysis of the $<2 \mu \mathrm{m}$ fractions shows that dioctahedral K-rich mica-like structures (referred to as illite or muscovite) is present in all the samples with the majority also containing $\mathrm{Chl}$ (Fig. 5). Chlorites have poorly developed $14 \AA$ peaks, indicating high iron content suggestive of chamositic compositions (Moore and Reynolds, 1997). Other phases such as ordered illite/smectite (I/S) or Pg and 


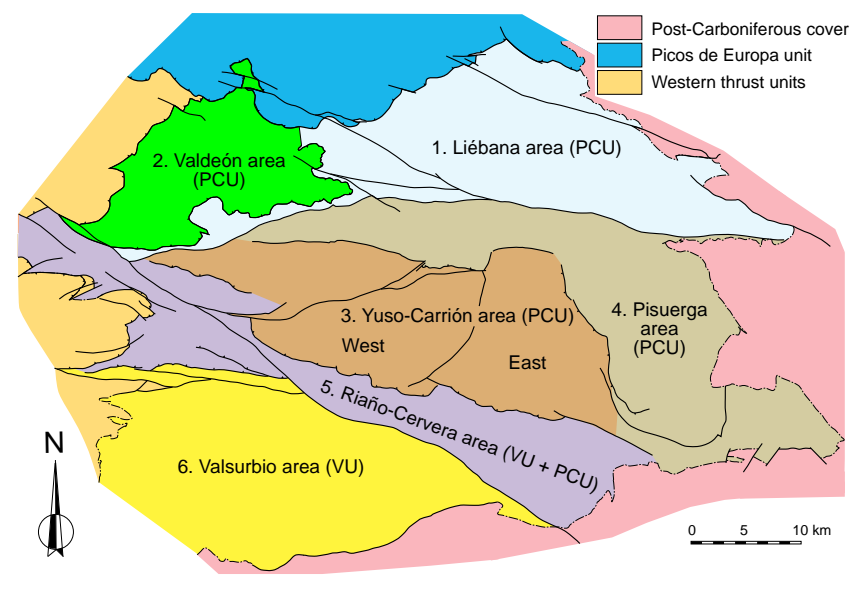

Figure 4. Diagrammatic map indicating the areas in which the study units have been subdivided, following Martín-Merino et al. (2014).

mixed layers $\mathrm{Pg} / \mathrm{Ms}$ are also common. Asymmetry of peaks and sample behaviour after glycolation indicate the presence of ordered illite/smectite (I/S). Absence of random I/S indicate that zone 3 of Eberl (1993) has been reached, suggesting that temperatures exceeded $100^{\circ} \mathrm{C}$. Kaolinite $(\mathrm{K} \ln )$ and pyrophyllite may also be present in some samples and are abundant in a few samples. In addition, Cld is also present and widespread in the study area. However, it is more abundant in samples close to the intrusions and/or faults in which case is found together with chlorite and $\mathrm{Pg}+\mathrm{Pg} / \mathrm{Ms}$. Only in samples to the east (Pisuerga Area), where it is not as abundant, may it be associated with Prl, Kln or I/S. Finally, chlorite/vermiculite mixed layer(C/V) and stilpnomelane (Stp) have been found, in small amounts, in a few samples and are restricted to samples to the eastern Pisuerga and eastern Yuso-Carrión areas.

The I/S is more abundant to the north and east (Valdeón, Liébana, and eastern part of the Pisuerga and Yuso-Carrión areas) and the presence of $\mathrm{Kln}$ is almost restricted to samples to the east (Pisuerga and eastern part of the Yuso-Carrión areas). Prl is common in samples from the central and northeastern parts (Liébana and Pisuerga areas and eastern part of the Yuso-Carrión area) (Fig. 5). Quartz, calcite, feldspars and goethite were accessory phases recognised in some samples.

In general the assemblages found are, in order of abundance of the most frequent phase besides illite $(n=291)$,

\footnotetext{
$\mathrm{I}+\mathrm{Chl}(n=215) \pm \mathrm{Pg} \pm \mathrm{Pg} / \mathrm{Ms} \pm \mathrm{Cld} \pm \mathrm{I} / \mathrm{S} \pm[\mathrm{C} / \mathrm{V}] \pm[\mathrm{Prl}] \pm[\mathrm{Kln}] \pm[\mathrm{Stp}]$

$\mathrm{I}+\mathbf{P g}+\mathbf{P g} / \mathbf{M s}(n=162) \pm \mathrm{Chl} \pm \mathrm{Cld} \pm[\mathrm{I} / \mathrm{S}] \pm[\mathrm{Prl}] \pm[\mathrm{C} / \mathrm{V}] \pm[\mathrm{Kln}] \pm[\mathrm{Stp}]$

$\mathrm{I}+\mathbf{I} / \mathbf{S}(n=112) \pm \mathrm{Chl} \pm \mathrm{Kln} \pm \mathrm{Prl} \pm \mathrm{C} / \mathrm{V} \pm \mathrm{Pg} \pm \mathrm{Pg} / \mathrm{Ms} \pm \mathrm{C} / \mathrm{V} \pm[\mathrm{Cld}] \pm[\mathrm{Stp}]$

$\mathrm{I}+\mathbf{C l d}(n=93) \pm \mathrm{Chl} \pm \mathrm{Pg} \pm \mathrm{Pg} / \mathrm{Ms} \pm \mathrm{I} / \mathrm{S} \pm[\mathrm{C} / \mathrm{V}] \pm[\mathrm{Prl}] \pm[\mathrm{Kln}] \pm[\mathrm{Stp}]$

$\mathrm{I}+\operatorname{Prl}(n=56) \pm \mathrm{I} / \mathrm{S} \pm \mathrm{Chl} \pm \mathrm{Pg} \pm \mathrm{Pg} / \mathrm{Ms} \pm \mathrm{C} / \mathrm{V} \pm[\mathrm{Cld}] \pm[\mathrm{Kln}] \pm[\mathrm{Stp}]$

$\mathrm{I}+\mathbf{C} / \mathbf{V}(n=48) \pm \mathrm{I} / \mathrm{S} \pm \mathrm{Chl} \pm \mathrm{Pg} \pm \mathrm{Pg} / \mathrm{Ms} \pm \mathrm{Kln} \pm \operatorname{Prl} \pm \mathrm{Cld} \pm[\mathrm{Stp}]$

$\mathrm{I}+\mathbf{K} \ln (n=39) \pm \mathrm{I} / \mathrm{S} \pm \mathrm{Chl} \pm \mathrm{C} / \mathrm{V} \pm[\mathrm{Prl}] \pm[\mathrm{Cld}] \pm[\mathrm{Pg}] \pm[\mathrm{Pg} / \mathrm{Ms}] \pm[\mathrm{Stp}]$
}

\subsubsection{Kübler index}

As mentioned above, determination of KI has been hampered by the presence in some samples of certain types of I/S and big amounts of $\mathrm{Pg}$ or Prl, in relation to the amount of illite, that interfere with the 001 peak of illite, therefore rendering their KI values useless for grade determination using KI, even in the glycolated state. As a result, 23 (indicated in italic in Supplement 2) of the 291 samples studied yielded doubtful KI values (Figs. 6, 7; Supplement 2). They are included, nevertheless, as they indicate maximum value of the KI.

Grade ranges from deep diagenetic to epizonal, but deep diagenetic and mainly low anchizonal metapelites are predominant in most of the areas (Figs. 6 and 7). Expandability of the $10 \AA$ peak is only lost at the high anchizone to epizone boundary. Deep diagenetic areas can be found to the north (Liébana and Valdeón areas). The Riaño-Cervera area is mainly low anchizonal with a few samples being diagenetic or deep anchizonal. In the Pisuerga area, the grade ranges from deep diagenetic to low anchizonal (Figs. 6,7). Higher-grade (epizonal) samples may appear in any formation and they are more abundant in the western part of the Yuso-Carrión area, where the Peña Prieta granodiorite is located, and in the Devonian of the Valsurbio area (Fig. 7). In both cases, it is in those high-grade samples where chloritoid is more abundant (Fig. 6).

Work in progress on the variation of the chemical composition of the phyllosilicates of the study area allowed estimation of temperatures using Battaglia's (2004) approach based in the variation in the chemical composition of illites. Temperatures obtained are in the range $230-280^{\circ} \mathrm{C}$, consistent with the anchizonal KI values of the analysed samples. The observed deficit in layer charge (Brime and Valín, 2006) is characteristic of anchizonal $\mathrm{K}$ white mica (Hunziker et al., 1986; Livi et al., 1997; Merriman and Peacor, 1999; Árkai, 2002; Árkai et al., 2003).

\subsection{3 Árkai index}

The AI has been measured in 118 samples, most, if not all of them, containing various amounts of $\mathrm{I} / \mathrm{S}$ and $/ \mathrm{or} \mathrm{Pg}-\mathrm{Pg} / \mathrm{Ms}$. Of them, 40 yielded diagenetic values, 63 low anchizonal values, 14 high anchizonal values and just 1 epizonal value. Distribution of these values can be seen in Fig. 6. In those cases in which $\mathrm{KI}$ and $\mathrm{AI}$ have been determined, the correlation of the grade indicated by both indices is good $(r=0.65$; significance level $\left.0.1 \% r_{60}=0.41\right)$, suggesting that both phases were formed under the same conditions and supporting the reliability of the $\mathrm{AI}$ as indicator of grade in those cases in which it is the only index available (Árkai et al., 1995).

The existence of some discrepancies between $\mathrm{KI}$ and $\mathrm{AI}$ may be caused by the presence of small amounts of I/S or $\mathrm{Pg}$ that alter the width of the illite peaks. However, those discrepancies are always small and are usually in samples 


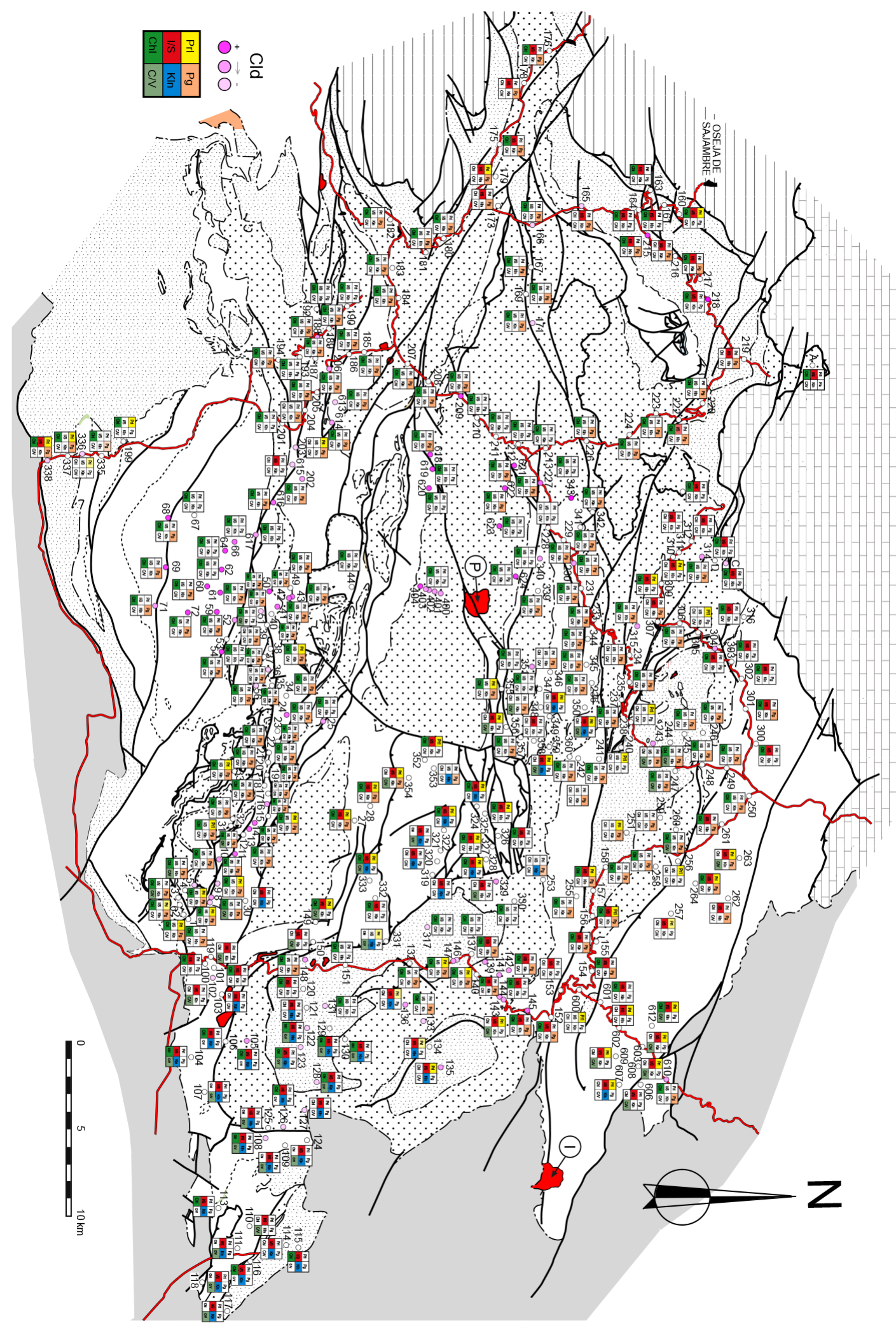

Figure 5. Distribution of clay minerals in the study area. All the samples contain illite and therefore this phase has not been considered in the plot. Presence of a certain phase in the sample is indicated by the colour in the corresponding square. I - Pico Iján granodiorite; P - Peña Prieta granodiorite. For legend see Fig. 8. 


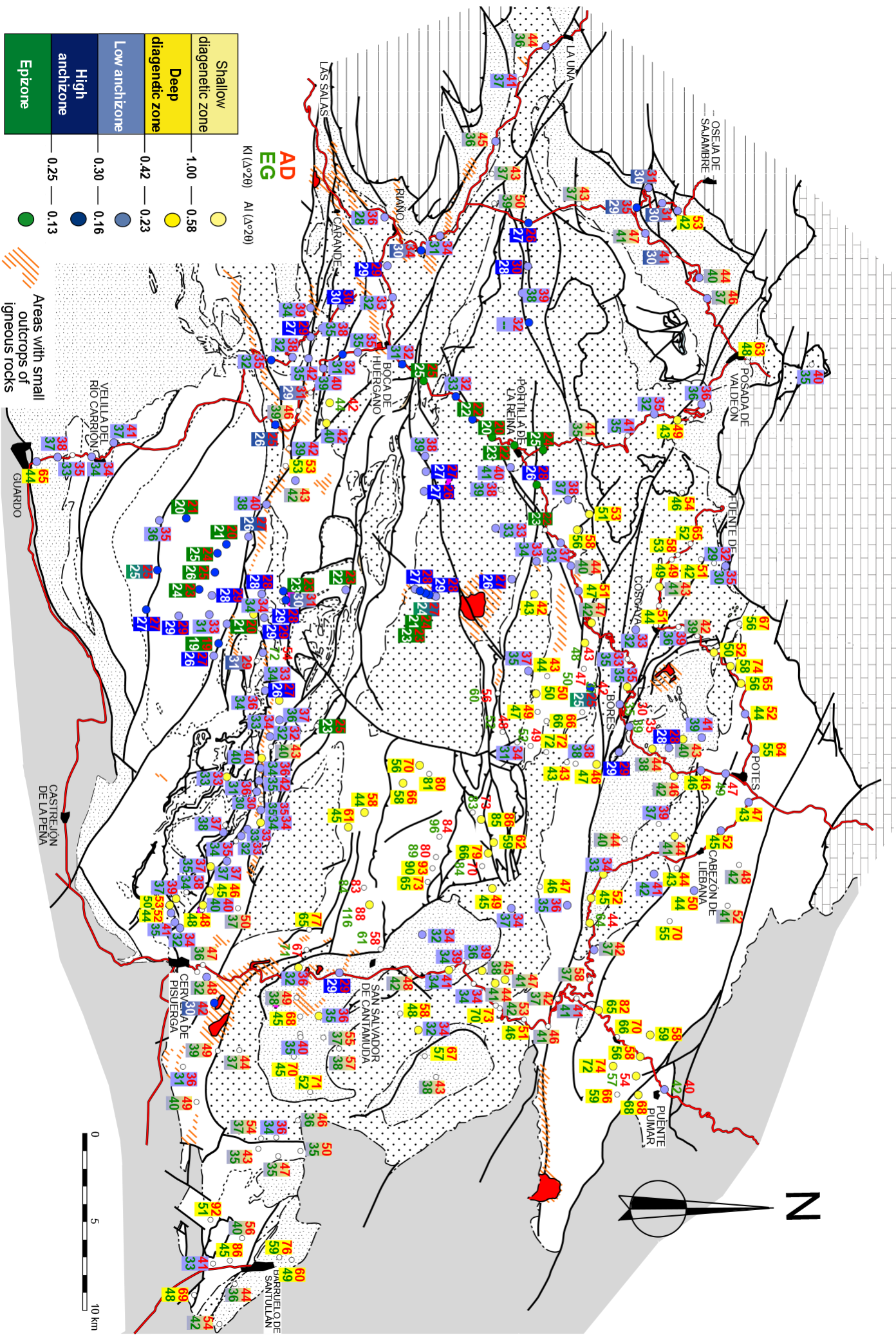

Figure 6. Map showing the location of Kübler index $(\mathrm{KI})$ values $(\times 100)$ (Kübler scale). Upper value, in red, is the air-dried sample; lower value, in green, is the sample treated with ethylene glycol. Árkai index (AI) is indicated by the colour of the sampling point. Values corresponding to samples with significant amounts of $\mathrm{I} / \mathrm{S}$, Prl and/or $\mathrm{Pg}-\mathrm{Pg} / \mathrm{Ms}$ have not been highlighted with grade colours. For legend see Fig. 8. 


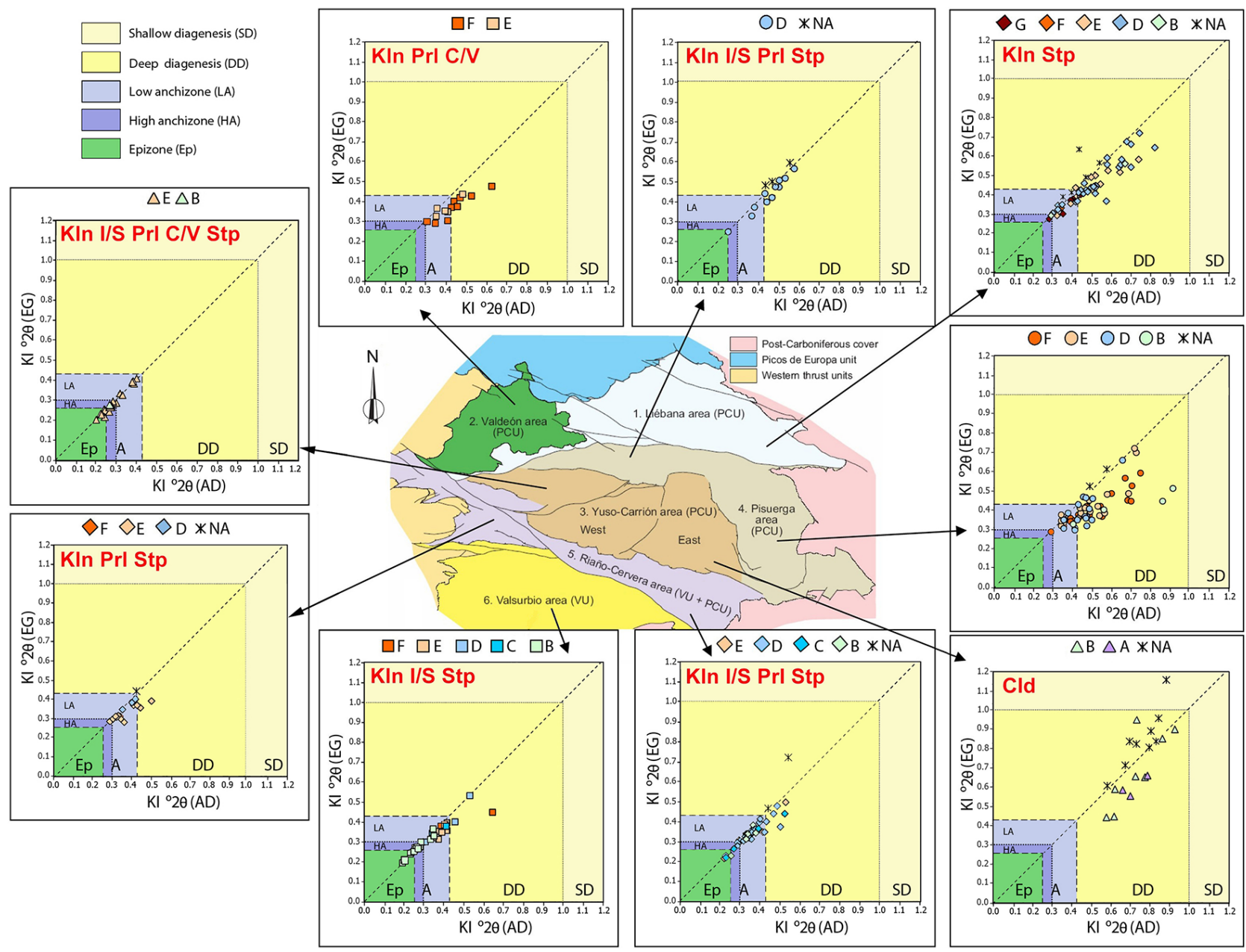

Figure 7. Plot of Kübler index (KI) measured on air-dried (AD) vs. KI measured on ethylene glycol solvated samples (EG), standardised at Kübler scale. DD - shallow diagenesis; LA - low anchizone; HA - high anchizone; Ep - epizone. Samples are plotted according to the areas outlined in Fig. 4 and have been grouped following the divisions of Fig. 2: A - Silurian; B - Devonian; C - Tournaisian-Visean; D - Prioro Group; E - Pando Group; F - Viorna Group; G - Campollo-Remoña Group. Samples with significant amounts of I/S, Prl and/or Pg-Pg/Ms are indicated as NA (not applicable). Minerals absent in each of the areas are indicated in red.

at the boundary between metamorphic-grade zones (Supplement 2).

\subsubsection{Mineral distribution in relation with grade}

Kaolinite is present in deep diagenetic samples and also in some low anchizonal ones. Maximum stability temperature of $\mathrm{Kln}$ is $270^{\circ} \mathrm{C}$, according to laboratory experiments (Velde, 1992), and therefore in agreement with its presence in the anchizonal samples. Paragonite, apart from its presence in deep diagenetic samples, is more frequently present in the anchizone and some epizonal samples (Figs. 5 and 6). Pyrophyllite is more abundant in samples from the anchizone but it can also be present in diagenetic samples.

The widespread occurrence of Kln and quartz in the diagenetic rock samples may provide the starting material for the formation of Prl by the reaction

1 kaolinite +2 quartz $\rightarrow 1$ pyrophyllite $+1 \mathrm{H}_{2} \mathrm{O}$,

as suggested in the Glarus Alps by Frey (1978), who considered Prl an indicator of anchizonal regional conditions. In fact of the 53 samples in which Prl is present, Kln is found, and in very small amounts, in only 8 of them. However, the stability field of Prl is strongly influenced by water activity, and thus the formation temperature could be notably lower (Thompson, 1970; Winkler, 1979; Hemley et al., 1980). Its presence in diagenetic samples is not uncommon and could be due to the influence of magmatic fluids (Hosterman et al., 1970; Kisch, 1987). According to Kisch (1987), Prl appears in regional terrains only in the anchizone but in areas of intrusive activity it may appear in lower-grade zones. Therefore, the presence of Prl in samples with diagenetic KI / AI values, 
as in the eastern part of the Liébana and Yuso-Carrión areas, could be regarded as evidence for high geothermal gradients or magmatic heating.

Chloritoid is abundant in samples from the high anchizone to epizone (south-eastern Valsurbio area and western YusoCarrión area), but it can also be present, in smaller amounts, in low anchizonal $(1,3 \mathrm{~W}, 4 \mathrm{E}, 4 \mathrm{~W}, 5 \mathrm{E}, 5 \mathrm{~W})$ and even diagenetic samples (eastern Liébana, Pisuerga and Riaño-Cervera areas). Cld is $\mathrm{Fe}$ rich. The average $\mathrm{Mg} /(\mathrm{Fe}+\mathrm{Mg}$ ) found is $<0.12$ (Brime and Valín, 2006), similar to that of pelites subjected to intermediate $P / T$ conditions. It is noteworthy that when this phase is present in the samples (a total of 93 samples have Cld), Prl is absent, or in very minor amounts in a few samples (10 in total), indicating that it could have been formed according to the reaction originally proposed by Zen (1960), which is generally accepted for the formation of Cld during metamorphism of aluminous pelites (Theye et al., 1992):

Pyrophyllite + chlorite $\rightarrow$ chloritoid + quartz $+1 \mathrm{H}_{2} \mathrm{O}$.

The absence of Cld in the eastern part of the Yuso-Carrión area where Prl is abundant, together with Chl, could indicate that the temperature required for its formation by Reaction (R3) has not been reached.

Presence of some $\mathrm{Fe}$ oxides has been detected in samples from the study area. Therefore more Cld could be produced by the reaction suggested by Bucher and Frey (1994):

$\mathrm{Chl}+4$ hematite $=\mathrm{Cld}+4$ magnetite $+2 \mathrm{Qtz}+3 \mathrm{H}_{2} \mathrm{O}$.

However, it has been observed in thin sections that occurrence of Prl is almost restricted to veins and fracture zones, suggesting that Cld could have been formed during the hydrothermal alteration of the pelites following the reaction proposed by Phillips (1988):

Chlorite $\rightarrow$ chloritoid + Fe-rich phase + quartz $+1 \mathrm{H}_{2} \mathrm{O}$.

Presence of Cld in the anchizone has been discussed by Kisch (1983), who concluded that Cld cannot unequivocally be regarded as an indicator of the beginning of the epizone, as previously suggested, because there are occurrences in the anchizone (Árkai et al., 1981). In the study area, Cld is more abundant in the epizonal samples of the Valsurbio (6) and western Yuso-Carrión (3W) areas, but it is also present in low anchizonal and a few deep diagenetic samples from the Riaño-Cervera (5E), Pisuerga (4E) or Valdeón (2) areas, thus corroborating the conclusion of Kisch (1983).

Cld and Prl are widespread in virtually all rock types and grade conditions (Supplement 2). This occurrence could be related to basin-wide alteration by infiltrating hydrothermal fluids (Phillips, 1988; Brime and Valín, 2006). Late- to postVariscan fluid flow events have been described in the other areas of the CZ (Ayllón et al., 2003; Gasparrini et al., 2003) and some of them have been related to a more general Variscan event (Boni et al., 2000).

\subsection{Conodont colour alteration index}

The CAI values are in general independent of the stratigraphic position of the samples (Figs. 8 and 9). The Kasimovian-Gzhelian rocks show lower values, but the small number of samples makes this result insignificant. CAI values vary widely, ranging from 1.5 to 7.5 , corresponding respectively to intervals of temperatures of $<40-60$ and $550-590^{\circ} \mathrm{C}$ (see Supplement 1). However, values equal to or lower than 2 are unusual, being limited to the southeastern sector of the Pisuerga-Carrión unit. Some samples with conodonts having high CAI values and a range of one and a half units, or more, are indicative of contact metamorphism and/or hydrothermal processes. Values $\geq 6$ are usually found close to outcrops of igneous rocks. The upper boundary of the ancaizone $(\mathrm{CAI}=4)$ corresponds to a temperature range of $190-225^{\circ} \mathrm{C}$, while the lower limit $(\mathrm{CAI}=5.5) \mathrm{cor}-$ responds to the range of $340-375^{\circ} \mathrm{C}$.

The lack of carbonate rocks prevents in some areas the construction of a complete map of CAI isograds; however, it is possible to observe that they crosscut the trend of the Variscan structures. CAI data allow the distinguishing of the following sectors in the study area (Fig. 8).

(a) Northern sector (Liébana and Valdeón areas): this is an ancaizonal area that passes without thermal discontinuity through the basal thrust of the Picos de Europa unit. Inside this unit, the boundary ancaizone/diacaizone appears and the CAI decreases northwards (Bastida et al., 2004; Blanco-Ferrera et al., 2011).

(b) Central-eastern sector (eastern part of the Yuso-Carrión area) with dominance of ancaizonal conditions: in the areas where CAI data exist a remarkable homogeneity of CAI values appears, mainly in the Devonian rocks of the area located to the east of the Curavacas-Lechada syncline.

(c) Central and western sectors (western part of the YusoCarrión and Riaño-Cervera areas): the limited CAI data available indicate that epicaizonal areas coexist with ancaizonal areas.

(d) Southern sector: corresponds to the VU and presents a wide area with epicaizonal conditions (García-López et al., 2013).

(e) South-eastern sector (eastern part of the Yuso-Carrión and Pisuerga areas): diacaizonal conditions are dominant, but ancaizonal and epicaizonal areas also appear. The latter areas appear adjacent to outcrops of igneous rocks. The greater variation of CAI values is found in this area, with a range from 1.5 to 7 .

The apparently chaotic distribution of CAI isograds could be due to a heat from subsurface intrusions at depth resulting in isotherms having complex geometry. This pattern may 


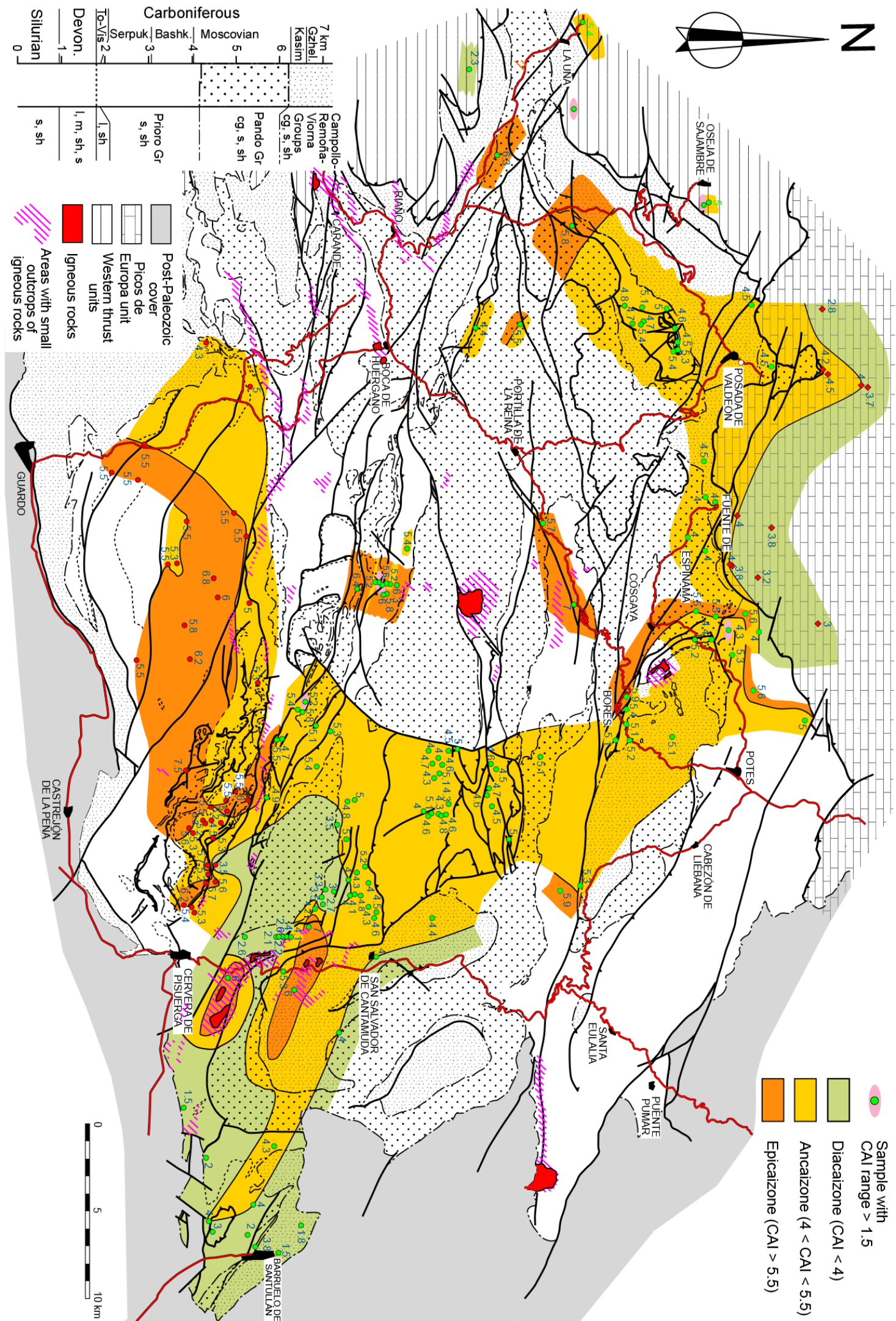

Figure 8. Map with location of CAI values and delimitation of CAI isograds. Picos de Europa CAI data after Bastida et al. (2004); Valsurbio CAI data after García-López et al. (2013). Symbols of the CAI samples as in Fig. 2. 


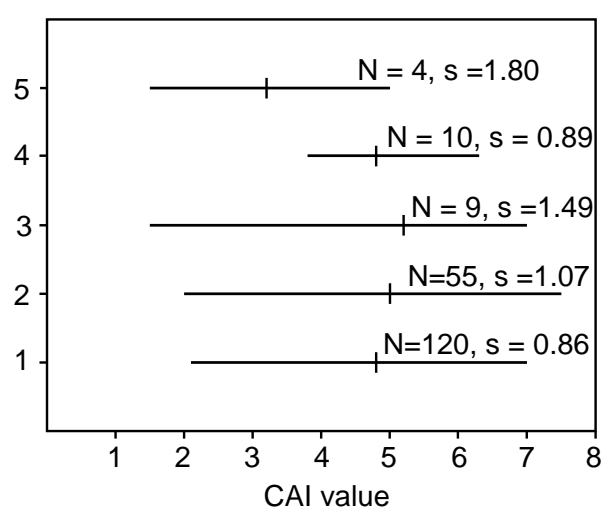

Figure 9. Diagram showing the distribution of CAI values in the different stratigraphic levels. The small vertical straight segments represent the mean value and the horizontal segments the CAI range. $\mathrm{N}$ - number of data; s - standard deviation. (1) Silurian-Devonian; (2) Tournaisian to lowermost Serpukhovian; (3) lower Serpukhovian to lowermost Moscovian (Prioro Group); (4) lower-upper Moscovian (Pando Group); (5) Kasimovian-Gzhelian.

be related to a crustal thinning during an extensional episode and to the subsequent intrusion of igneous bodies that emplaced at different levels, generating contact metamorphism and hydrothermal fluids.

In general, conodonts of the study area are undeformed and well preserved. Most of them have granular texture due to apatite recrystallisation under high temperature. The apatite crystals do not show preferential orientation and their size increases with temperature. The granular texture is commonly incipient for CAI values between 4 and 4.5 and is widespread for CAI values $\geq 5$. Furthermore, some conodonts with CAI values between 6 and 7 have coarse recrystallisation, corrosion and loss of ornamentation, so that in a few cases they have lost their original morphology ("ghost conodonts"). These alterations of conodonts with CAI values $\geq 5$ are indicative of contact metamorphism and hydrothermal processes. Some conodonts with $\mathrm{CAI} \geq 4.5$ present sets of parallel microfissures, probably related to the rock cleavage. Conodonts with $\mathrm{CAI} \leq 4$ have occasionally unaltered surfaces, but most of them present a sugary texture (dull, frosted or pitted surfaces). The surfaces of these conodonts show several types of overgrowth of apatite crystals, mainly developed in the diacaizone, irrespective of the thermal conditions inside this zone; they were usually a result of apatite solution and crystallisation processes (Blanco-Ferrera et al., 2011).

\subsection{Cleavage development and tectonothermal evolution}

Two main cleavages have been found in the study area (Fig. 10). Cleavage $S_{1}$ is a rough foliation associated with upright folds and trends approximately E-W; it appears mainly in the northern half of the study area. This cleavage affects the latest Carboniferous rocks (Kasimovian-Gzhelian age). Cleavage $S_{2}$ dips gently, crosscuts earlier upright folds and is associated with the development of metre-scale open cascade folds. It is especially well developed in the CuravacasLechada syncline (Fig. 11) and in the VU. Both cleavages appear in different areas and have not been observed superimposed. The existence of two cleavages with different age suggests that two tectonothermal events took place in the south-eastern sector of the CZ.

The first event, associated with the $S_{1}$ cleavage (subvertical), is not well defined, since it developed in an area where presence of I/S and Kln and KI and AI values indicate deep diagenesis or low anchizonal conditions, and CAI values dominantly show ancaizonal conditions. According to the age of the latest rocks affected, this event probably occurred during the late Gzhelian. It resulted in crustal thickening produced by the $\mathrm{N}-\mathrm{S}$ shortening that gave rise to the emplacement of the Picos de Europa unit, the last major Variscan thrust unit that was generated in the foreland fold and thrust belt, and to the development of other thrusts and folds to the south of this unit.

The second event produced cleavage $S_{2}$ that crosscuts the upright folds in the southern part of the study area (Curavacas-Lechada syncline and the VU). Under the microscope, this cleavage shows evidences of pressure solution and crystallisation of oriented muscovite and chlorite with formation of chlorite-muscovite porphyroblasts. XRD indicates that the rocks affected by this cleavage present $\mathrm{Chl}+\mathrm{Pg}-\mathrm{Pg} / \mathrm{Ms}$ assemblages; $\mathrm{KI}$ and $\mathrm{AI}$ values indicate high anchizonal to epizonal conditions and CAI values indicate similar conditions. The gently dipping attitude of $S_{2}$ suggests that this event was associated with an extensional deformation. The event culminated with the intrusion of igneous rocks that pierced the rocks with cleavage and generated a contact metamorphism associated with hydrothermal processes, as indicated by (1) the widespread presence of Cld and Prl (Fig. 5; Brime and Valín, 2006) and low KI and AI values, (2) recrystallisation in conodonts (granular texture), (3) high CAI values in samples close to outcrops of intrusive rocks, (4) a wide range of CAI in some samples and (5) irregular variation of the CAI through the area and strong corrosion in some conodonts. The cleavage $S_{2}$ developed earlier than the porphyroblasts (biotite, andalusite and chloritoid) formed during the contact metamorphism associated with the granodioritic stock of Peña Prieta (Gallastegui et al., 1990; Rodríguez Fernández, 1994), whose age is Cisuralian $(292+2 /-3$ Ma after Valverde-Vaquero et al., 1999). These data suggest the development of a thermal event that took place near the boundary Carboniferous-Permian and that progressed during the Cisuralian with the intrusion of many small igneous bodies that rose along faults (Suárez and García, 1974; Corretgé and Suárez, 1990).

In some locations, $S_{2}$ is gently folded with local development of crenulation cleavage. This may be a result of the Alpine deformation, which is the only post-Variscan com- 

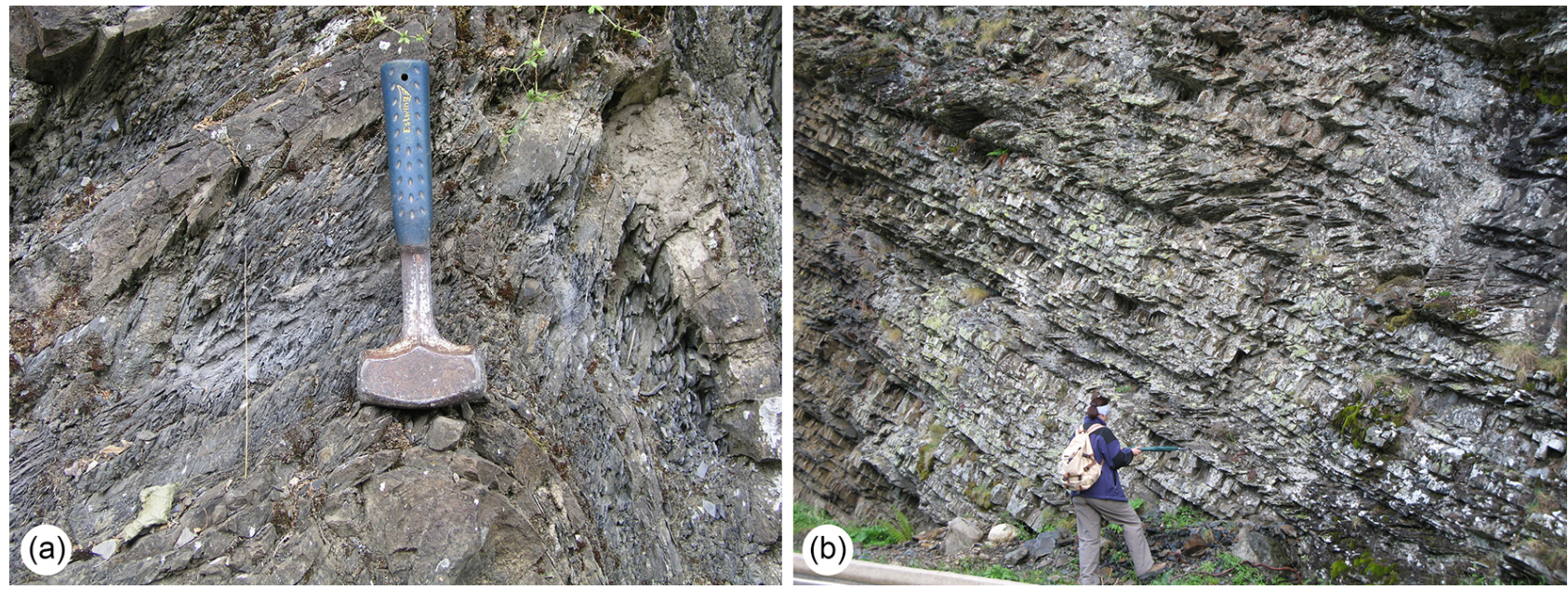

Figure 10. (a) $S_{1}$ cleavage associated with a nearly upright fold (eastern part of the Liébana area; north to the right). (b) $S_{2}$ cleavage dipping less than bedding in a normal stratigraphic succession (Pando Group; Curavacas-Lechada syncline; north to the left).

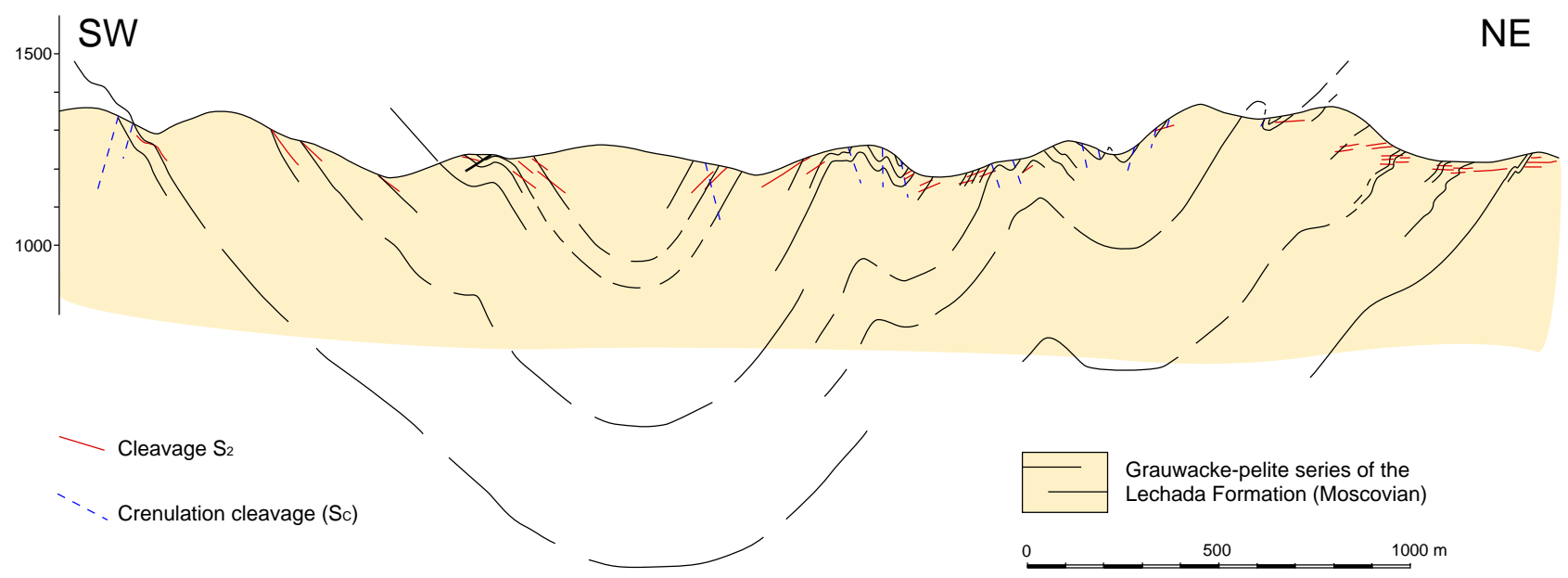

Figure 11. Cross section of the Curavacas-Lechada syncline showing the distribution of $S_{2}$ cleavage and crenulation cleavage. Location in Fig. 2.

pressional deformation described in the area (Gallastegui, 2000 and references therein), and involved a ductile deformation that required a moderate temperature and gave rise to a dome shape in the VU (Marín, 1997).

The features described above refer to penetrative structures or to the thermal history developed during the last stages of the Variscan evolution. However, this evolution does not preclude the development of other thermal episodes subsequently, such as the hydrothermal postVariscan episodes described by Boni et al. (2000), Muchez et al. (2005), Gasparrini et al. (2006) and Clauer and Weh (2014).

\section{Discussion}

The distribution of the different grade indicators used in the study area shows, in general, an acceptable correlation between them, although some discrepancies have been observed. All methods coincide in pointing out the location of the areas with higher metamorphic grade, being the CAI and the AI the indicators that tend to give the highest and the lowest grade respectively. All indices point to an irregular distribution of the areas with very-low-grade metamorphism. Diacaizonal areas are limited to the south-eastern sector. A discrepancy is observed in the eastern Yuso-Carrión area between clay mineral and CAI data; a notable number of CAI values systematically indicates ancaizonal conditions, whereas clay assemblages with abundant $\mathrm{I} / \mathrm{S}$ and $\mathrm{Kln}, \mathrm{KI}$ and $\mathrm{AI}$ indicate diagenetic conditions. 
Table 1. Tectonothermal evolution of the south-eastern sector of the Cantabrian Zone.

\begin{tabular}{ll}
\hline Variscan deformation & $\begin{array}{l}\text { Emplacement of north-directed Palentine nappes (prior or earliest } \\
\text { Moscovian) and the adjacent western Cantabrian nappes (late Mosco- } \\
\text { vian) with associated thrusts in the PCU }\end{array}$ \\
\hline Variscan deformation (cont.) & $\begin{array}{l}\text { Emplacement of the south-directed Picos de Europa unit; thrusts and } \\
\text { folds in the PCU (Kasimovian-Gzhelian) }\end{array}$ \\
\hline N-S shortening) & $\begin{array}{l}\text { Upright folds and axial plane cleavage }\left(S_{1}\right) \text {; first tectonothermal event } \\
\text { with deep diagenetic - low anchizonal and ancaizonal areas in the north- } \\
\text { ern part of the PCU (late Gzhelian) }\end{array}$ \\
\hline $\begin{array}{l}\text { Late-Variscan gravitational } \\
\text { readjustment; extensional event }\end{array}$ & $\begin{array}{l}\text { Gently dipping cleavage ( } S_{2} \text { ) associated with crosscutting folds; sec- } \\
\text { ond tectonothermal event; very-low- or low-grade metamorphism } \\
\text { (high anchizone-epizone, and ancaizone-epicaizone) in the Curavacas- }\end{array}$ \\
$\begin{array}{l}\text { Lechada syncline and the VU. Normal faults (late-most Gzhelian to } \\
\text { early Cisuralian) }\end{array}$ \\
\hline $\begin{array}{l}\text { Intrusion of igneous rocks, contact metamorphism and wide develop- } \\
\text { ment of hydrothermal processes (Cisuralian) }\end{array}$ \\
\hline $\begin{array}{l}\text { Extension linked to the } \\
\text { Basque-Cantabrian basin }\end{array}$ \\
\hline Alpine deformation & $\begin{array}{l}\text { P-S shortening, tightening of gentle folds, local crenulation cleavage } \\
\text { and tilting of rocks northwards (Cenozoic). }\end{array}$ \\
\hline
\end{tabular}

The correlation among the different indicators that can be used to establish the metamorhic grade is challenging due to several factors, such as the different kinetics of the processes that modify the colour of the conodonts and the transformation of the clay minerals and the different influence of fluids in limestones and pelitic rocks. These processes could explain the discrepancies observed.

In the context of the $\mathrm{CZ}$, the low-grade extensional metamorphism of the PCU extends westwards and allows an elongated area to be defined that can be followed up to the Central Coal Basin (Fig. 1) (Aller, 1981, 1986; Brime, 1985; Aller et al., 1987, 2005; García-López et al., 2007). The biggest width of this zone is in the study area, coinciding with the core of the Ibero-Armorican Arc, where a special evolution occurred in the context of the CZ. The last stages of arc tightening gave rise to strong shortening with formation of folds and cleavage $\left(S_{1}\right)$ in the core of the arc, and the corresponding crustal thickening and heating (late Gzhelian). Subsequently, a gravitational instability in this core produced an extensional episode during which low-grade metamorphism and subhorizontal cleavage $\left(S_{2}\right)$ crosscutting previous folds developed in some areas. This evolution continued during the Cisuralian with the intrusion of igneous bodies and associated contact metamorphism whose minerals post-date the $S_{2}$ cleavage. The existence of a crustal thickening followed by a gravitational instability in the core of the Ibero-Armorican Arc has also been proposed by other authors (GutiérrezAlonso et al., 2004, 2011). In the Central Coal Basin, the metamorphism associated with subhorizontal cleavage and crosscutting folds has been related to the possible existence of igneous bodies in depth (Aller, 1986) or to the rise of fluids along faults, especially the León fault (Aller et al., 2005). In the metamorphic southern part of the study area (VU), the metamorphism disappears westward, so that the adjacent western unit of the Esla nappe region is not metamorphic (García-López et al., 2013; Valín and Brime, unpublished data).

The existence of hydrothermal alteration has been suggested by Brime and Valín (2006) and Clauer and Weh (2014). The common occurrence of Cld and Prl and the irregular distribution of CAI values, the wide range in the high CAI values in some samples and textural alterations of conodonts agree with the occurrence of hydrothermal fluids and possible subsurface igneous bodies. As for the thermal events dated by Clauer and Weh (illite K-Ar; 2014), the first has an age (293 $\pm 3 \mathrm{Ma})$, comparable to that of the Peña Prieta granitoid, and the others (Guadalupian, middle Triassic and early-middle Jurassic) are probably related to the crustal extension associated with the Basque-Cantabrian basin. Specific structural evidences of these three later events have not been found and their temperatures were probably lower than those of the late-Variscan extensional episode, which, being related to igneous intrusions, probably gave rise to the palaeothermal peak.

The zircon (U-Th)/He ages obtained by Fillon et al. (2016) in three samples from our study area indicate that they had probably a temperature above $180^{\circ} \mathrm{C}$ before exhumation started by $37-39 \mathrm{Ma}$ ago (Eocene). This is consistent with the local occurrence of crenulation cleavage associated with Alpine ductile deformation. 
The proposed tectonothermal evolution of the studied region from Variscan up to Alpine times is summarised in Table 1 .

\section{Conclusions}

Study of the low-grade metamorphic rocks and associated structures in the south-eastern sector of the $\mathrm{CZ}$ has allowed a model for the tectonothermal evolution of the core of an arcuate orogenic belt to be developed. This core, although a part of a foreland fold and thrust belt where diagenetic conditions are dominant, portrays a complex evolution due to its special location inside the belt. It was thrust during the Carboniferous by large units from south, west and north, which resulted in a great accumulation of syntectonic sediments and development of unconformities and structures. The latter arose as a result of compression in different directions that also generated a crustal thickening. The emplacement of the last thrust unit (Picos de Europa unit) produced a N-S shortening that generated thrusts and associated folds. Shortly afterwards, upright folds with E-W trend and associated cleavage $\left(S_{1}\right)$ developed, mainly in the northern part of the sector. The ductile deformation occurred under thermal conditions which reached the anchizone and the ancaizone in some areas. This represents the first tectonothermal event registered in the south-eastern sector of the CZ.

At the end of the Variscan deformation, gravitational instability gave rise to an extensional episode and the corresponding crustal thinning. During this event an increase in the thermal gradient enabled ductile deformation and lowgrade metamorphism to take place in some areas (second tectonothermal event), mainly in the central part (CuravacasLechada syncline) and the southern part (Valsurbio unit) of the sector. The ductile deformation produced gently dipping cleavage $\left(S_{2}\right)$ crosscutting earlier upright $F_{1}$ folds. Some small, open cascade folds were also produced. The metamorphism reached epizonal and epicaizonal conditions during this event. The process culminated in the Cisuralian with the intrusion of igneous rocks and the development of contact metamorphism around the larger igneous bodies. In the case of Peña Prieta granodiorite, post- $S_{1}$ andalusite porphyroblasts developed. Hydrothermal fluids were common during this extensional episode, resulting in the development of Prl and Cld, textural alteration and high CAI dispersions in conodont samples.

As a whole, the metamorphic grade is independent of the stratigraphic location of the samples and the trend of the main structures, indicating the late-orogenic character of the tectonothermal events. The thermal level decreases progressively northwards inside the adjacent Picos de Europa unit. However, the metamorphism associated with the extensional episode in the PCU is extended westwards as an elongated area whose development was probably favoured by the rise of fluids along faults, especially along the León fault.

\section{Information about the Supplement}

Supplement 1 contains conodont CAI values and temperatures inferred from the CAI Arrhenius plot (Epstein et al., 1977; Rejebian et al., 1987). (V: Valsurbio samples; P: Pisuerga-Carrión samples; Po: Ponga samples; Pe: Picos de Europa samples). Supplement 2 contains the following.

1. Values of KI measured on air-dried vs. KI measured on ethylene glycol solvated samples, standardised at Kübler scale. Samples are grouped according to the areas outlined in Fig. 4. Samples with significant amounts of $\mathrm{I} / \mathrm{S}$ and $\mathrm{Pg}-\mathrm{Pg} / \mathrm{Ms}$ that have not been plotted in Figs 6 and 7 are indicated with Roman letter type of smaller size.

2. AI measured on air-dried samples.

3. Clay minerals present in the samples. Capitals and bold type indicate more abundance of the phase.

\section{The Supplement related to this article is available online at doi:10.5194/se-7-1003-2016-supplement.}

Acknowledgements. This paper is dedicated to the memory of Andrés Pérez Estaún in recognition to his major contribution to the study the geology of the Variscan belt in Spain and his pioneer work on the low-grade metamorphism of the area and in gratitude for fruitful cooperation over a period of many years. The present paper has been supported by the CGL2015-66997-R project funded by the Ministerio de Economía y Competitividad of Spain. The authors acknowledge Dr. Robin Offler, who read an earlier version of this paper and suggested improvements. Susana García-López acknowledges the cooperation of C. F. Winkler Prins from the National Museum of Natural History (Leiden, Netherlands) and H. Jahnke from the Institut und Museum für Geologie und Paläontologie (Göttingen, Germany) for providing access to the Cantabrian conodont collections of these institutions. We thank Joaquina Álvarez-Marrón, Tom Blenkinsop, Josep Poblet and an anonymous referee for useful suggestions for improving the manuscript.

Edited by: J. Alvarez-Marron

\section{References}

Aller, J.: La estructura del borde sudoeste de la Cuenca Carbonífera Central (Zona Cantábrica, NW de España), Trabajos de Geología, 11, 3-14, 1981.

Aller, J.: La estructura del sector meridional de las unidades del Aramo y Cuenca Carbonífera Central, Principado de Asturias, Spain, 180 pp., 1986. 
Aller, J., Bastida, B., Brime, C., and Pérez-Estaún, A.: Cleavage and its relation with metamorphic grade in the Cantabrian Zone (Hercynian of North-West Spain), Sci. Géol. Bull., 40, 255-272, 1987.

Aller, J., Valín, M. L., García-López, S., Brime, C., and Bastida, F.: Superposition of tectono-thermal episodes in the southern Cantabrian Zone (foreland thrust and fold belt of the Iberian Variscides, NW Spain), Bull. Soc. Géol. France, 176, 503-514, 2005.

Alonso, J. L. and Rodríguez Fernández, L. R.: Las discordancias carboníferas de la región del Pisuerga-Carrión (Cordillera Cantábrica, NO de España). Significado orogénico, Comptes Rendus del X Congreso Internacional de Estratigrafía y Geología del Carbonífero, Instituto Geológico y Minero de España, Madrid, Spain, 533-540, 1983

Alonso, J. L., Marcos, A., and Suárez, A.: Paleogeographic inversion resulting from large out of sequence breaching thrusts: The León Fault (Cantabrian Zone, NW Iberia), A new picture of the external Variscan Thrust belt in the Ibero-Armorican Arc, Geol. Acta, 7, 451-473, doi:10.1344/105.000001449, 2009.

Ambrose, T., Carballeira, J., López Rico, J., and Wagner, R. H.: Mapa Geológico de España E, 1: 50000 , Hoja No. 107, Inst. Geol. Min., España, 1984.

Árkai, P.: Chlorite crystallinity: an empirical approach and correlation with illite crystallinity, coal rank and mineral facies as exemplified by Palaeozoic and Mesozoic rocks of northeast Hungary, J. Metamorph. Geol., 9, 723-734, 1991.

Árkai, P.: Phyllosilicates in very low-grade metamorphism: transformation to micas, in: Micas: crystal chemistry and metamorphic petrology, Mineralogical Society of America, edited by: Mottana A., Sassi, F. P., Thompson J. B., and Guggenheim, S., Blacksburg, Virginia, Rev. Mineral. Geochem., 46, 463-478, 2002.

Árkai, P., Horváth, Z. A., and Tóth, M.: Transitional very low-and low-grade regional metamorphism of the Paleozoic formations, Uppony Mountains, NE-Hungary: mineral assemblages, illitecrystallinity, -vitrinite reflectance data, Acta Geol. Acad. Sci. Hung, 24, 265-294, 1981.

Árkai, P., Sassi, F. P., and Sassi, R.: Simultaneous measurements of chlorite and illite crystallinity: a more reliable tool for monitoring low- to very low grade metamorphism in metapelites, A casse study from the Southern Alps (NE Italy), Eur. J. Mineral., 7, 1115-1128, 1995.

Árkai, P., Faryad, S. W., Vidal, O., and Balogh, K.: Very low-grade metamorphism of sedimentary rocks of the Meliata unit, Western Carpathians, Slovakia: implications of phyllosilicate characteristics, Int. J. Earth Sci., 92, 68-85, 2003.

Árkai, P., Sassi, F. P., and Desmonds, J.: 5. Very low- to low-grade metamorphic rocks. Recommendations by the IUGS Subcommission on the Systematics of Metamorphic rocks, Web version of 01/02/07, 2007.

Ayllón, F., Bakker, R. J., and Warr, L. N.: Re-equilibration of fluid inclusions in diagenetic-anchizonal rocks of the CiñeraMatallana coal basin (NW Spain), Geofluids, 3, 49-68, 2003.

Bastida, F., Brime, C., García-López, S., and Sarmiento, G. N.: Tectonothermal evolution in a region with thin skinned tectonics: the western nappes in the Cantabrian Zone (Variscan belt of NW Spain), Int. J. Earth. Sci. (Geol. Rundsch.), 88, 38-48, 1999.
Bastida, F., Brime, C., García-López, S., Aller, J., Valín, M. L., and Sanz López, J.: Tectonothermal evolution of the Cantabrian Zone (NW Spain), in: Palaeozoic conodonts from northern Spain, editors: García-López, S. and Bastida F., Cuadernos del Museo Geominero 1, Inst. Geol. Miner., Madrid, Spain, 105-23, 2002.

Bastida, F., Blanco-Ferrera, S., García-López, S., Sanz-López, J., and Valín, M. L.: Transition from diagenesis to metamorphism in a calcareous tectonic unit of the Iberian Variscan belt (Central massif of the Picos de Europa, NW Spain), Geol. Mag., 141, 617-628, 2004.

Battaglia, S.: Variations in the chemical composition of illite from five geothermal fields: a possible geothermometer, Clay Miner., 39, 501-510, 2004.

Blanco-Ferrera, S., Sanz-López, J., García-López, S., Bastida, F., and Valín, M. L.: Conodont alteration and tectonothermal evolution of a diagenetic unit in the Iberian Variscan belt (Ponga-Cuera unit, NW Spain), Geol. Mag., 148, 35-49, 2011.

Boni, M., Iannace, A., Bechstädt, T., and Gasparrini, M.: Hydrothermal dolomites in SW Sardinia (Italy) and Cantabria (NW Spain): evidence for late- to post-Variscan widespread fluid-flow events, J. Geochem. Explor. 69/70, 225-228, 2000.

Brime, C.: A diagenesis to metamorphism transition in the Hercynian of north-west Spain, Mineral. Mag., 49, 481-484, 1985.

Brime, C.: Metamorfismo de bajo grado: ¿diferencias en escala o diferencias en grado metamórfico?, Trabajos de Geología, 21, 61-66, 1999.

Brime, C. and Valín, M. L.: Asociaciones con cloritoide en rocas de bajo grado metamórfico de la Unidad del Pisuerga-Carrión (Zona Cantábrica, NO de España), Macla, 6, 105-108, 2006.

Brime, C., Talent, J. A., and Mawson, R.: Low-grade metamorphism in the Palaeozoic sequence of the Townsville hinterland, northeastern Australia, Aust. J. Earth Sci., 50, 751-767, 2003.

Brouwer, A.: Deux facies dans le Dévonien des montagnes cantabriques meridionales, Breviora Geológica Astúrica, VIII, 3-10, 1964.

Bucher, K. and Frey, M.: Petrogenesis of Metamorphic Rocks, $6^{\text {th }}$ Edn. Springer-Verlag, Berlín, 318 pp., 1994.

Clauer, N. and Weh, A.: Time constraints for the tectono-thermal evolution of the Cantabrian Zone in NW Spain by illite K-Ar dating, Tectonophysics, 623, 39-51, 2014.

Colmenero, J. R. and Prado, J. G.: Coal basins in the Cantabrian Mountains, Northwestern Spain, Int. J. Coal Geol., 23, 215-229, 1993.

Colmenero, J. R., Suárez-Ruiz, I., Fernández-Suárez, J., Barba, P., and Llorens, T.: Genesis and Rank distribution of Upper Carboniferous coal basins in the Cantabrian Mountains, Northern Spain, Int. J. Coal Geol, 76, 187-204, 2008.

Colmenero, J. R., Vargas, I., García-Ramos, J. C., Manjón, M., Creapo, A., and Matas, J.: Mapa Geológico de España E. 1: 50 000, Hoja No 132, Guardo, Inst. Geol. Min. España, 1982.

Corretgé, L. G. and Suárez, O.: Igneous rocks of the cantabrian/Palentian Zone, in: Pre-Mesozoic Geology of Iberia, edited by: Dallmeyer R. D. and Martínez García, E., Springer, Berlin, 72-79, 1990.

Corretgé, L. G., Cienfuegos, I., Cuesta, A., Galán, G., Montero, P., Rodríguez Pevida, L. S., Suárez, O., and Villa, L.: Granitoides de la Región Palentina (Cordillera Cantábrica, España), Actas e Comunicaçoes, IX Reuniao sobre a Geologia do Oeste Peninsular (Porto, 1985), Memorias Univ. Do Porto, 1, 469-478, 1987. 
Eberl, D. D.: Three zones for illite formation during burial diagenesis and metamorphism, Clays Clay Miner., 41, 26-37, 1993.

Engelder, T. and Marshak, S.: Disjunctive cleavage formed at shallow depths in sedimentary rocks, J. Struct. Geol., 7, 327-343, 1985.

Epstein, A. G., Epstein, J. B., and Harris, L. D.: Conodont color alteration-an index to organic metamorphism, Washington, DC., Geol. Surv. Prof. Pap., 995, 1-27, 1977.

Essene, E. J. and Peacor, D. R.: Clay mineral thermometry - a critical perspective, Clays Clay Miner., 43, 540-553, 1995.

Ferreiro Mählmann, R., Petrova, T. V., Pironon, J., Stern, W. B., Ghanbaja, J., Dubessy, J., and Frey, M.: Transmission electron microscopy study of carbonaceous material in a metamorphic profile from diagenesis to amphibolite facies (Bündnerschiefer, eastern Switzerland), Schweiz, Mineral. Petrogr. Mitt., 82, 253 272, 2002.

Fillon, C., Pedreira, D., van der Beek, P., Huismans, R. S., Barbero, L., and Pulgar, J. A.: Alpine exhumation of the central Cantabrian Mountains, Northwest Spain, Tectonics, 35, 339-356, 2016.

Frankenfeld, H.: El manto del Montó-Arauz; interpretación estructural de la Región del Pisuerga-Carrión (Zona Cantábrica España), Trabajos de Geología, 13, 37-47, 1983.

Frey, M.: Progressive low-grade metamorphism of a black shale formation, Central Swiss Alps, with special reference to pyrophyllite and margarite bearing assemblages, J. Petrol., 19, 1, 95-135, 1978.

Frey, M.: Very low-grade metamorphism of clastic sedimentary rocks, in: Low temperature metamorphism, edited by: Frey M., Blackie, Glasgow, 9-58, 1987.

Frey, M., Teichmüller, M., Teichmüller, R., Müllis, J., Künzi, B., Breitschmid, A., Gruner, U., and Schwizer, B.: Very low grade metamorphism in external parts of the Central Alps: illite crystallinity, coal rank and fluid inclusion data, Eclogae Geol. Helv., 73, 173-203, 1980

Gallastegui, J.: Estructura cortical de la cordillera y margen continental cantábricos: perfiles ESCI-N, Trabajos de Geología, 22, 9-234, 2000.

Gallastegui, G., Heredia, N., Rodríguez Fernández, L. R., and Cuesta, A.: El "stock" de Peña Prieta en el contexto del magmatismo de la Unidad del Pisuerga-Carrión (Zona Cantábrica, N de España), Cuadernos do Laboratorio Xeolóxico de Laxe, 15, 203-215, 1990.

García-López, S., Brime, C., Bastida, F., and Sarmiento, G. N.: Simultaneous use of thermal indicators to analyse the transition from diagenesis to metamorphism: an example from the Variscan Belt of northwest Spain, Geol. Mag., 134, 323-334, 1997.

García-López, S., Bastida, F., Brime, C., Aller, J., Valín, M. L., Sanz-López J., Méndez, C. A., and Menéndez-Álvarez, J. R.: Los episodios metamórficos de la Zona Cantábrica y su contexto estructural, Trabajos de Geología, 21, 177-187, 1999.

García-López, S., Bastida, F., Aller, J., and Sanz-López J.: Geothermal palaeogradients and metamorphic zonation from the conodont colour alteration index (CAI), Terra Nova, 13, 79-83, , 2001.

García-López, S., Blanco-Ferrera, S., and Sanz-López, J.: Aplicación de los conodontos al conocimiento de la evolución tectonotérmica de las zonas externas de los orógenos, Revista Española de Micropaleontología, 38, 289-298, 2006.
García-López, S., Brime, C., Valín, M. L., Sanz-López J., Bastida, F., Aller, J., and Blanco Ferrera, S.: Tectonothermal evolution of a foreland fold and thrust belt: the Cantabrian Zone (Iberian Variscan belt, NW Spain), Terra Nova, 19, 469-475, 2007.

García-López, S., Bastida, F., Aller, J., Sanz-López, J., Marín, J. A., and Blanco Ferrera, S.: Tectonothermal evolution of a major thrust system: the Esla-VU (Cantabrian Zone, NW Spain), Geol. Mag., 150, 1047-1061, 2013.

Gasparrini, M., Bakker, R. J., Bechstädt, T., and Boni, M.: Hot dolomites in a Variscan foreland belt: hydrothermal flow in the Cantabrian Zone (NW Spain), J. Geochem. Explor., 78/79, 501507, 2003.

Gasparrini, M., Bechstädt, T., and Boni, M.: Massive hydrothermal dolomites in the southwestern Cantabrian Zone (Spain) and their relation to the Late Variscan evolution, Mar. Pet. Geol., 23, 543$568,2006$.

Gómez-Fernández, F., Mangas, J., Both, R. A., and Arribas, A.: Metallogenesis of the $\mathrm{Zn}-\mathrm{Pb}$ deposits of the southeastern region of the Picos de Europa (Cantabria, Spain), in: Current research in geology applied to ore deposits, edited by: Fenoll Hach-Ali, P., Torres-Ruiz J., and Gervilla F., Univ. Granada, Granada, Spain, 113-116, 1993.

Gómez-Fernández, F., Both, R. A., Mangas, J., and Arribas, A.: Metallogenesis of $\mathrm{Zn}-\mathrm{Pb}$ carbonate-hosted mineralization in the southeastern region of the Picos de Europa (Central Norhern Spain) Province: geologic, fluid inclusion, and stable isotopes studies, Econ. Geol., 95, 19-40, 2000.

Groshong Jr., R. H., Pfiffner, O. A., and Pringle, L. R.: Strain partitioning in the Helvetic thrust belt of eastern Switzerland from the leading edge to the internal zone, J. Struct. Geol, 6, 5-18, 1984.

Guggenheim, S., Bain, D. C., Bergaya, F., Brigatti, M. F., Drits, V. A., Eberl, D. D., Formoso, M. L. L., Galán, E., Merriman, R. J., Peacor, D.R., Stanjek, H., and Watanabe, T.: Report of the Association Internationale pour l'Etude des Argiles (AIPEA) Nomenclature Committee for 2001: order, disorder, and crystallinity in phyllosilicates and the use of the "Crystallinity Index", Clays Clay Miner., 50, 406-409, 2002.

Gutiérrez-Alonso, G., Fernández-Suárez, J., and Weil, A.: Orocline triggered lithospheric delamination, in: Orogenic Curvature: Integrating Paleomagnetic and Structural Analyses, edited by: Sussman, A. J. and Weil, A. B., Geol. Soc. Am. Special Paper, 383, 121-130, 2004.

Gutiérrez-Alonso, G., Murphy, J. B., Fernández-Suárez, J., Weil, A., Piedad Franco, M., and Gonzalo, J. C.: Lithospheric delamination in the core of Pangea: $S_{\mathrm{m}}-N_{\mathrm{d}}$ insights from the Iberian mantle, Geology, 39, 155-158, 2011.

Hemley, J. J., Monteya, J. W., Marinenko, J. W., and Luce, R. W.: Equilibria in the system $\mathrm{Al}_{2} \mathrm{O}_{3}-\mathrm{SiO}_{2}-\mathrm{H}_{2} \mathrm{O}$ and some general implications for alteration mineralization processes, Econ. Geol., 75, 210-228, 1980.

Heredia, N., Alonso., J. L., and Rodríguez Fernández, L. R. Mapa Geológico de España E. 1 : 50 000, Hoja No 105, Riaño, Inst. Geol. Min. España, 1997.

Heredia, N., Navarro, D., Rodríguez Fernández, L. R., Pujalte, V., and García Mondéjar., J.: Mapa Geológico de España E. 1 : 50 000, Hoja No 82, Tudanca, Inst. Geol. Min. España, 1986.

Heredia, N., Rodríguez Fernández, L. R., Suárez, A., and Álvarez Marrón, J.: Mapa Geológico de España E. 1 : 50 000, Hoja No 80, Burón, Inst. Geol. Min. España, 1991. 
Hosterman, J. W., Wood, G. H., and Beryin, M. J.: Mineralogy of underclays in the Pennsylvania anthracite region, US Geological Survey Professional Paper 700-C, C89-C97, 1970.

Hunziker, J. C., Frey, M., Clauer, N., Dallmeyer, R. D., Friedrichsen, H., Flehmig, W., Hochstrasser, K., Roggwiler, P., and Schwander, H.: The evolution of illite to muscovite: mineralogical and isotopic data from Glarus Alps, Switzerland, Contrib. Mineral. Petrol., 92, 157-180, 1986.

Julivert, J. and Navarro, D.: Mapa Geológico de España E. 1: 50 000, Hoja No 55, Beleño, Inst. Geol. Min. España, 1984.

Julivert, M.: Décollement tectonics in the Hercynian Cordillera of NW Spain, Am. J. Sci., 270, 1-29, 1971.

Julivert, M.: Hercynian orogeny and Carboniferous paleogeography in northwestern Spain: A model of deformation-sedimentation relationships, Z. Dt. Geol. Ges., 129, 565-592, 1978.

Julivert, M., Ramirez del Pozo, J., and Truyols, J.: Le reseau de failleset la couverture post-hercynienne dans les Asturies, in: Histoire structurale du Golfe de Gascogne, Publications de l'Institute Francais du Pétrole, Editions Tech. 2, V.3.1-V.3.34, 1971.

Keller, M. and Krumm, S.: Variscan versus Caledonian and Precambrian metamorphic events in the Cantabrian Mountains, Z. dt. Geol. Ges., 144, 88-103, 1993.

Kisch, H. J.: Mineralogy and petrology of burial diagenesis (burial metamorphism) and incipient metamorphism in clastic rocks, in: Diagenesis in sediments and sedimentary rocks, edited by: Larsen, G. and Chilingar, G. V., 2. Elsevier, Amsterdam, 289493 and 513-541, 1983.

Kisch, H. J.: Correlation between indicators of very-low grade metamorphism, in: Low temperature metamorphism, edited by: Frey, M., Blackwell Science, Claridge, 227-300, 1987.

Kisch, H. J.: Illite crystallinity: recommendations on sample preparation, X-ray diffraction settings and interlaboratory settings, J. Metamorph. Geol., 9, 665-670, 1991.

Kisch, H. J., Árkai, P., and Brime, C.: On the calibration of the illite Kübler index (illite "crystallinity”), Schweiz, Mineral. Petrogr. Mitt., 84, 232-331, 2004.

Köberle, T., Keller, M., and Krumm, S.: Metamorphism in the southeastern corner of the Cantabrian Mountains as revealed by the Upper Devonian Murcia Quartzite, Zbl. Geol. Paläont. Teil I, 5/6, 447-460, 1998.

Koopmans, B. N.: The sedimentary and structural history of the Valsurvio dome, Cantabrian Mountains, Spain, Leidse. Geol. Med., 26, 121-232, 1962.

Kübler, B.: La cristallinité d'illite et les zones tout à fait supérieures du metamorphism. Etages tectoniques.Université Neuchâtel à la Baconnière, Neuchâtel, Switzerland, Colloques de Neuchâtel 1966, 105-122, 1967.

Livi, K. J. T., Veblen, D.R., Ferry, J. M., and Frey, M.: Evolution of 2:1 layered silicates in low-grade metamorphosed Liassic shales of Central Switzerland, J. Metamorph. Geol., 15, 323-344, 1997.

Llorens, T., Suárez-Ruiz, I., and Colmenero J. R.: Petrografía de los carbones cantabrienses (Carbonífero sup.) del Grupo Cea de la Cuenca Guardo-Valderrueda (León-Palencia), Geogaceta, 40, 279-282, 2006.

Lobato, L.: Geología de los valles altos de los ríos Esla, Yuso, Carrión y Deva. Institución Fray Bernardino de Sahagún, León (C.S.I.C.), 192 pp., 1977.
Lobato, L., Rodríguez Fernández, L. R., Heredia, N., Velando, F., and Matas, J: Mapa Geológico de España E. 1 : 50 000, Hoja No 106, Camporredondo de Alba, Inst. Geol. Min. España, 1985.

López-Fernández, C., Pulgar, J. A., Glez.-Cortina, J. M., Gallart, J., Díaz, J., and Ruiz, M.: Actividad sísmica en el noroeste de la Península Ibérica observada por la red sísmica local del Proyecto GASPI (1999-2002), Trabajos de Geología, 24, 91-106, 2004.

Maas, K.: The geology of Liébana, Cantabrian Mountains, Spain: Deposition and Deformation in a flysch area, Leidse. Geol. Med., 49, 379-465, 1974.

Marcos, A. and Pulgar, J. A.: An approach to the tectonostratigraphic evolution of the Cantabrian Foreland thrust and fold belt, Hercynian Cordillera of NW Spain, Neues Jahrb. Geol. Paläontol. Abh., 163, 256-260, 1982.

Marín, J. A.: Estructura del domo de Valsurbio y borde suroriental de la región del Pisuerga-Carrión (Zona Cantábrica, NO de España), Unpublished Ph. D. thesis, Oviedo University, 181 pp., 1997.

Marín, J. A., Pulgar, J. A., and Alonso, J. L.: La deformación alpina en el Domo de Valsurvio (Zona Cantábrica, NO de España). Revista de la Sociedad Geológica de España, 8, 111-116, 1995.

Marín, J. A., Villa, E., García-López, S., and Menéndez, J. R.: Estratigrafía y metamorfismo del Carbonífero de la zona de San Martín-Ventanilla (Norte de Palencia, Cordillera Cantábrica), Revista de la Sociedad Geológica de España, 9, 241-251, 1996.

Marquínez, J. and Marcos, A.: La estructura de la unidad del GildarMontó (Cordillera Cantábrica), Trabajos de Geología, 14, 53-64, 1984.

Martínez García, E., Marquínez, J., Heredia, N., Navarro, D., and Rodríguez Fernández, L. R.: Mapa Geológico de España E. 1 : 50000 , Hoja No 56, Carreña-Cabrales, Inst. Geol. Min. España, 1984.

Martín-Izard, A, Palero, F. J., Regillón, R., and Vindel, E.: El skarn de Carracedo (San Salvador de Cantamuda). Un ejemplo de mineralización pirometasomática en el N. de la provincia de Palencia, Stvdia Geologica Salmanticensia, XXIII, 171-192, 1986.

Martín-Merino, G., Fernández, L. P., Colmenero, J. R., and Bahamonde, J. R.: Mass-transport deposits in a Variscan wedge-top foreland basin (Pisuerga area, Cantabrian Zone, NW Spain), Mar. Geol., 356, 71-87, 2014.

Merino-Tomé, O. A., Bahamonde, J. R., Colmenero, J. R., Heredia, N., Villa, E., and Farias, P.: Emplacement of the Cuera and Picos de Europa imbricate system at the core of the Iberian-Armorican arc (Cantabrian zone, Nord Spain: New precisions concerning the timing of arc closure, Geol. Soc. Am. Bull., 121, 729-751, 2009.

Merriman R. J. and Peacor D. R.: Very low-grade metapelites: mineralogy, microfabrics and measuring reaction progress, in: LowGrade Metamorphism, Blackwell Science, edited by: Frey, M. and Robinson, D., Oxford, 10-60, 1999.

Merriman, R. J. and Frey, M.: Patterns of very low-grade metamorphism in metapelitic rocks, in: Low grade metamorphism, edited by: Frey, M. and Robinson, D., Blackwell Science, London, 61107, 1999.

Meunier, A.: Clays, Springer-Verlag, Berlín, Heidelberg, New York, 2005.

Moore, D. M. and Reynolds Jr., R. C.: X-ray diffraction and the identification and analysis of clay minerals, 2nd Edn., Oxford University Press, New York, 1997 
Muchez, P., Heijlen, W., Banks, D., Blundell, D., Boni, M., and Grandia, F.: Extensional tectonics and the timing and formation of basin-hosted deposits in Europe, Ore Geol. Rev. 27, 241-264, 2005.

Müllis, J.: The system methane-water as a geologic thermometer and barometer from the external parts of the Central Alps, B. Minéral., 102, 526-536, 1979.

Müllis, J., Rahn, M. K., De Capitani, C., Stern, W. B., and Frey, M.: How useful is illite "crystallinity" as a geothermometer?, Terra Nova, 7, 128-129, 1995.

Müllis, J., Rahn, M. K., Schwer, P., De Capitani, C., Stern, W. B., and Frey, M.: Correlation of fluid inclusion temperatures with illite "crystallinity" data and clay minerals chemistry in sedimentary rocks from the external parts of the Central Alps, Schweiz, Mineral. Petrogr. Mitt., 82, 325-340, 2002.

Passchier, C. W. and Trouw, R. A. J.: Microtectonics, 2nd Edn., Springer, Berlin, 366 pp., 2005.

Patrick, B. E., Evans, B. W., Dumoulin, J. A., and Harris, A. G.: A comparison of carbonate mineral and conodont color alteration index thermometry, Seward Peninsula, Alaska, Geological Society of America, Abstracts with programs, 17, 399 pp., 1985.

Phillips, G. N.: Widespread fluid infiltration during metamorphism of the Witwatersrand goldfields: generation of chloritoid and pyrophyllite, J. metamorph. Geol., 6, 311-332, 1988.

Raven, J. G. M. and van der Pluijm, B. A.: Metamorphic fluids and transtension in the Cantabrian Mountains of northern Spain: an application of the conodont color alteration index, Geol. Mag., 123, 673-681, 1986.

Rejebian, V. A., Harris, A. G., and Huebner, J. S.: Conodont color and textural alteration: an index to regional metamorphism, contact metamorphism, and hydrothermal alteration, Geol. Soc. Am. Bull., 99, 471-479, 1987.

Rodríguez Fernández, L. R.: La estratigrafía del Paleozoico y la estructura de la región de Fuentes Carrionas y áreas adyacentes (Cordillera herciniana, NO de España), Cuadernos do Laboratorio Xeolóxico de Laxe, Serie Nova Terra, 9, A Coruña, 240 pp. 1994.

Rodríguez Fernández, L. R. and Heredia, N.: La estratigrafía del Carbonífero y la estructura de la unidad del Pisuerga-Carrión. NO de España, Cuadernos do Laboratorio Xeolóxico de Laxe, 12, 207-229, 1987.

Rodríguez Fernández, L. R., Heredia, N., Navarro, D., MartinezGarcía, E., and Marquínez, J.: Mapa Geológico de España E. 1 : 50000 , Hoja No 81, Potes. Inst. Geol. Min. España, 1994.

Savage, J. F.: Tectonic analysis of Lechada and Curavacas synclines, Yuso basin, León, NW Spain, Leidse. Geol. Med., 39, 193-247, 1967.
Środoń, J.: X-ray powder diffraction of illitic materials, Clays Clay Miner., 32, 337-349, 1984.

Suárez, O. and Corretgé, L. G.: Plutonismo y metamorfismo en las zonas Cantábrica y Asturoccidental-leonesa, in: Geología de los granitoides y rocas asociadas del Macizo Hespérico (libro homenaje a L. C. García de Figuerola), edited by: Bea, F., Carnicero, A., Gonzalo, J. C., López Plaza, M., and Rodríguez Alonso, A. D., Ed. Rueda, Madrid, 13-25, 1987.

Suárez, O. and García, A.: Petrología de la granodiorita de Peña Prieta (León, Santander, Palencia), Acta Geol. Hispanica, 9, 154$158,1974$.

Theye, T., Seidel, E., and Vidal, O.: Carpholite, sudoite, and chloritoid in low-grade high-pressure metapelites from Crete and The Peloponnese, Greece, Eur. J. Mineral., 4, 487-507, 1992.

Thompson, A. P.: A note on the kaolinite-pyrophillie equilibrium, Am. J. Sci., 268, 454-458, 1970.

Valverde-Vaquero, P., Cuesta, A., Gallastegui, G., Suárez, O., Corretgé, L. G., and Dunning, G. R.: U-Pb dating of late Variscan magmatism in the Cantabrian Zone (Northern Spain), Meeting of the European Union of Geosciences 10 (EUG 10), Strasbourg, Journal of Conference, Abstracts, 4, p. 101, 1999.

Van der Pluijm., B. A., Savage, J. F., and Kaars-Sijpestijn, C. H.: Variation in fold geometry in the Yuso Basin, northern Spain: implications for de deformation regime, J. Struct. Geol., 8, 879886, 1986.

Van Veen, J.: The tectonic and stratigraphic history of the Cardaño area, Cantabrian Mountains, Northwest Spain, Leidse. Geol. Med., 35, 45-104, 1965.

Velde, B.: Introduction to clay minerals, Chapman and Hall, 198 pp., 1992

Von Gosen, W., Buggisch, W., and Krumms, S.: Metamorphism and deformation mechanisms in the Sierras Australes fold and thrust belt (Buenos Aires Province, Argentina), Tectonophysics, 185, 335-356 1991.

Warr, L. N. and Rice, H. N.: Interlaboratory standardization and calibration of clay mineral crystallinity and crystallite size data, J. Metamorph. Geol., 12, 141-152, 1994.

Winkler, H. G. F.: Petrogenesis of metamorphic rocks, 5th edition, Srpinger Verlag New York, 348 pp., 1979.

Zen, E.-A.: Metamorphism of Lower Paleozoic rocks in the vicinity of the Taconic Range in west-central Vermont, Am. Mineral., 45, 129-175, 1960. 